\title{
Réquiem para la dogmática penal. Una visión retrospectiva a la aplicación de la teoría de la imputación objetiva en la jurisprudencia de Colombia
}

Réquiem for the criminal Dogmatics.

A retrospective view of the application of the theory of Objective imputation in Colombian jurisprudence

Réquiem para a dogmatica criminal. Uma visão retrospectiva da aplicação da teoria do Objetivo de imputação na jurisprudência colombiana

Requiem pour dogmatique criminelle. Une vue rétrospective de l'application de la théorie de l'imputation objective dans la jurisprudence colombienne

\section{Ana Carolina Molina Villar ${ }^{1}$ Universidad Extremado de Colombia}

Revista Derechos en Acción

Año 3/NNo 8 Invierno 2018, 351-409

DOI: https://doi.org/10.24215/25251678e189.

ORCID: https://orcid.org/0000-0001-6615-1942

Recibido: 11/05/2018

Recibido con modificaciones: 26/06/2018

Aprobado: 23/08/2018

1 Cursante del programa intensivo del Doctorado en Derecho en la Universidad de Buenos Aires, Argentina. Magister en Ciencias Penales y Criminológicas (Universidad Extremado de Colombia); Especializada en Derecho Procesal Penal (Universidad Externado de Colombia); ex-Auxiliar de Magistrado do Tribunal Superior de Bogotá (enero de 2009 - febrero de 2011), actual Profesional grado 033 de la Sala de Casación de la Corte Suprema de Justicia de Colombia (agosto de 2012 - actualidad). Abogada (Universidad Externado de Colombia). 
Resumen: ¿Por qué los Colombianos fuimos/somos receptivos a la teoría de la imputación objetiva? ¿El sistema acusatorio y la justicia transicional han logrado poner en jaque a la dogmática penal? El presente escrito tiene como propósito indagar las posibles causas o razones por la que fuimos/somos receptivos a la teoría de la imputación objetiva en Colombia; así como, reseñar unas cuantas heridas de muerte causadas por la jurisprudencia a la dogmática jurídico- penal, mismas que motivan este réquiem.

Palabras claves: dogmática-derecho penal-imputación objetiva

Abstract: Why Colombians were / are receptive to the theory of objective imputation? The accusatory system and the transitional justice have been able to put in check the criminal dogmatic? This essay is intended to investigate possible causes or reasons for which we were / are receptive to the theory of objective imputation in Colombia; as well as review some wounds of death caused by jurisprudence to the criminal and legal dogmatic, the same wich motivates this requiem.

Keywods: dogmatics-criminal law-objective imputation

Resumo: Por que nós colombianos fomos / somos receptivos à teoria da imputação objetiva? 0 sistema acusatório e a justiça transicional têm conseguido colocar em xeque a dogmática penal? 0 presente estudo tem por propósito indagar as possíveis causas ou razões pelas quais fomos / somos receptivos à teoria da imputação objetiva na Colômbia; bem como revisar algumas feridas de morte causadas pela jurisprudência à dogmática jurídico - penal, as mesmas que motivam este réquiem

Palavras-chave: dogmática- direito penal- imputação objetiva

Résumé: Pourquoi les Colombiens ont adhéré à la théorie de l'imputation objective? Le système accusatoire et la justice transitionnelle ont-ils réussi à mettre en échec la dogmatique pénale? Le but de cet article est d'étudier les causes possibles ou les raisons pour lesquelles nous étions,et nous sommes encore, réceptifs à la théorie de l'imputation objective en Colombie; ainsi que de signaler quelques graves dommages causés par la jurisprudence aux dogmatiques de droit pénal, qui motivent ce requiem.

Mots-clés: dogmatique-droit pénal-imputation objective 


\section{Preámbulo}

Debo confesar que al culminar la lectura de la brillante obra "El crimen de tortura. En el Estado autoritario y en el Estado de Derecho" de la autoría del maestro Daniel Rafecas, releí más de una docena de veces el siguiente párrafo:

"Como consecuencia derivada de la conclusiones precedentes, puede afirmarse entonces que, en materia de tortura y demás tratos crueles, inhumanos o degradantes... actualmente no existen impedimentos de orden jurídico-penal ni de orden constitucional para la imputación penal de supuestos de hecho recurrentes que son presentados ante la agencia judicial... No obstante lo afirmado... quedó demostrado las dificultades que evidencia el Estado argentino cuando se trata de criminalizar este tipo de comportamientos". ${ }^{2}$

Y pensé ese mismo número de veces (doce) que mutatis mutandis ese diagnóstico a la realidad judicial argentina guardaba estrecha identidad con el de mi país, incluso por la ironía que encierra esa frase precitada, en cuanto a que todo esfuerzo teórico (léase, de la doctrina) para que se lleve a cabo una reforma normativa que nos aproxime a materializar la imparcialidad e igualdad en los fallos judiciales se puede ver frustrada por la irreflexiva dinámica judicial en la que se prefiere causar heridas mortales a la dogmática jurídico-penal antes que morigerar el criterio visceral o atemperar los pre-juiciosos morales.

Todo esfuerzo teórico (léase, de la doctrina) para que se lleve a cabo una reforma normativa que nos aproxime a materializar la imparcialidad e igualdad en los fallos judiciales se puede ver frustrada por la irreflexiva dinámica judicial en la que se prefiere causar heridas mortales a la dogmática jurídicopenal antes que morigerar el criterio visceral o atemperar los pre-juiciosos morales.

2 RAFECAS, D. "El crimen de tortura. En el Estado autoritario y en el Estado de Derecho." Editorial Didot, páginas 408 y 409. 
Respecto a este tópico el maestro ROXIN al citar a GIMBERNAT ORDEIG, señala:

\begin{abstract}
«entajas del pensamiento sistemático. El penalista español Gimbernat Ordeig ha descrito así, con una impresionante referencia a la situación en países con un sistema jurídico menos desarrollado, de modo sintético las ventajas del pensamiento dogmático: "la dogmática jurídico- penal, al señalar límites y definir conceptos, hace posible una aplicación segura y calculable del Derecho penal, y lo sustrae a la irracionalidad, a la arbitrariedad y a la improvisación. Cuanto más pobre sea el desarrollo de una dogmática, tanto más imprevisible serán las decisiones de los Tribunales" E invoca el peligro de que la decisión jurídica se convierta "en una lotería": "Y cuanto menor sea el desarrollo dogmático, tanto más crece esa lotería, hasta llegar a una situación de aplicación caótica y sin rumbo de un derecho penal". A ese respecto invoca también una afirmación mía, que ex negativo pretende por contraste presentar bajo una luz favorable las ventajas del pensamiento sistemático conceptual: "Donde están en juego pasiones humanas- $y$ en qué proceso penal no ocurre así, la fuente más turbia del conocimiento es un sentimiento jurídico no articulable conceptualmente" ${ }^{\text {". }}$.
\end{abstract}

La evolución de la dogmática jurídico -penal en Colombia puede explicarse desde las diferentes estructuras políticas que el Estado ha adoptado en el curso de los siglos XIX, XX y XXI. Empero, como quiera que es un tema que desbordaría el tópico que me he propuesto esbozar en el presente análisis, me limito a enunciar las distintas nominaciones que recibió la nación en 1860,1870 y 1880, lapso en el que se gestó el movimiento guerrillero: FARC; para, seguidamente, dar un salto de cien (100) años hasta alcanzar el siguiente hito histórico relevante para el presente análisis, atinente éste a la conformación de los carteles del narcotráfico y la creación del paramilitarismo,

3 ROXIN C, Derecho Penal, parte general, tomo I. Fundamentos. La estructura de la Teoría del delito. Editorial Civitas S.A. 1997, página 207. 
los dos actores bélicos que completan la triada de los que se convertirían en los principales destinatarios de la diferentes versiones de nuestra carta constitucional ${ }^{4}$ y de la legislación penal sustantiva y adjetiva.

\section{Siglo XIX}

- Confederación Granadina ${ }^{5}$. Década de los 60`s. Grupos guerrilleros de extrema izquierda de inspiración marxistaleninista comienzan a disputarle a los gobiernos de turno el monopolio del poder, dando origen a una guerra interna asimétrica de baja intensidad.

- Estados Unidos de Colombia ${ }^{6}$. Década de los 70's ${ }^{7}$. Mediante el Decreto Legislativo 3398 del 24 de diciembre de 1965 se crearon los denominados grupos de "autodefensa" o "paramilitares". En un comienzo se trató de un mandato del gobierno con vigencia transitoria; empero, mutó a permanente con la Ley 48 de 1968. Así, entonces, emergen grupos paramilitares de extrema derecha, los que financiados por los carteles

4 La Constitución Política de Colombia se constituye en la principal fuente de derecho penal. Que los principios básicos sobre los cuales se erige el derecho penal en mi país se logren estatuir en el texto constitucional, en "la norma de normas" (art. 2 C.P.C. 1991) suele ser objeto de exaltación por la doctrina foránea. Al respecto son las ilustrativas las siguientes palabras de un reconocido doctrinante mexicano: "Más recientemente CALDAS VERA prefiere adoptar una clasificación que distingue de las fuentes principales de las subsidiarias, considerando que las misma responde a la nomenclatura que trae la Constitución de Colombia. Las primeras, esto es, las fuentes principales, son en su opinión: la Constitución, la ley, o mejor el proceso legislativo, así como los actos administrativos de carácter general» PAVÓN VANSCONCELOS, FRANCISCO. MANUAL DE DERECHO PENAL MEXICANO. PARTE GENERAL, páginas 77 y 78. Editorial PORRÚA, AV. República Argentina, México, 2010. Texto en el cual se cita a CALDAS VERA, JORGE EMILIO. "FUENTES DEL DERECHO PENAL" Lecciones De Derecho Penal. Editorial Universidad Externado De Colombia, v., p.85-108- 1, 2011.

5 Constitución de la Confederación Granadina de 1858.

6 Constitución Política de los Estados Unidos de Colombia, sancionada el 8 de mayo de 1963. Al respecto ver en http://babel.banrepcultural.org/cdm/singleitem/collection/ p17054coll10/id/643

7 Constitución Política del Estado S. Cauca de 1972. Al respecto ver en http://babel.banrepcultural.org/cdm/singleitem/collection/p17054coll10/id/644 
de la droga y adoctrinados por los jefes de reconocidas bandas criminales, se suman a dicho conflicto bélico para "asesinar cualquier brote que estuviera enfocado a realizar un cambio sociopolitico en el país".

- Estado S. del Cauca9/ República de Colombia ${ }^{10}$. Década de los 80's. El conflicto armado interno tuvo un rápido escalamiento que se caracterizó por los actos delictivos de intimidación recíproca que los prenombrados actores perpetraron, cuyo efecto colateral iba desde el secuestro de familiares de narcotraficantes y periodistas, pasando por la tortura, homicidio y desaparición forzada de profesores universitarios y defensores de derechos humanos, hasta generar el homicidio masivo de la población civil, verbigracia, "masacre de Mapiripán"11.

\section{Siglo XX}

- 6 y 7 de noviembre de 1985. El Palacio de Justicia en Bogotá fue escenario de una sangrienta toma guerrillera (35 miembros del M-19) y recuperación militar que dejó cerca de

8 https://colombia2020.elespectador.com/pais/la-historia-del-paramilitarismo-en-colombia-segun-ronderos

9 Constitución Política del estado S. del Cauca de 1872. "A vuestro nombre y bajo la protección de Dios Supremo Legislador del Universo, hemos acordado, decretado y firmado la siguiente Constitución del Estado. En su penosa labor nos hemos guiado, sin vacilar, por el deseo ardiente de procurar vuestra felicidad, sin pasión alguna mezquina, tomando por base invariable la Constitución nacional federal, los preceptos más sanos de política y de moral social modernos, y de acuerdo en todo con el santo Evangelio cristiano y con las necesidades peculiares del Estado; en atención á la inmensa extensión de su territorio, a su exuberante fertilidad tropical y al genio altivo de sus hijos". http://babel.banrepcultural.org/cdm/singleitem/ collection/p17054coll10/id/644

10 Constitución política del 5 de agosto de 1886

11 "Un grupo de más de cien hombres que vestían prendas militares y portaban armas de corto y largo alcance, empezaron desde el martes 15 de julio y hasta la madrugada del domingo 20 de julio a ejecutar selectiva y gradualmente a habitantes del casco urbano y zona rural del municipio de Mapiripán (Meta), en límites con el departamento del Guaviare" fuente de consulta: http://www.eltiempo.com/archivo/documento/MAM-719064, buscado el 15 de febrero de 2018. 
un centenar de muertos, incluidos once magistrados de la Corte Suprema, y una profunda herida que el país aún no cierra.

- Década de los 90's. La degradación del conflicto alcanzó su mayor nivel con los secuestros masivos de políticos, narcotraficantes, periodistas y defensores de derechos humanos. El desplazamiento forzado, como conducta punible en la que incurrieron las AUC, FARC, ELN y narcotraficantes lograron cambiar los cuadros geopolíticos tradicionales. El éxodo de gran parte de la población civil del sector rural al urbano generó "una catástrofe humanitaria" comparable a la de "los Balcanes, la Europa Oriental, el África Central... Timor Oriental y Chechenia."12

- En el año de 1991 se promulgó una nueva Constitución Política, en la que se dio vida a la Fiscalía General de la Nación, un órgano autónomo e independiente, otorgándole el monopolio del ejercicio de la acción penal, esto es, investigar los hechos que revistan las características de un delito y acusar al autor o participe de esas conductas punibles ante el juez competente. Fue nuestra forma de ingresar a un sistema procesal mixto, en abandono de un modelo inquisitivo.

\section{Siglo XXI}

- En el año 2000 se expidieron dos nuevas legislaciones: el código penal (Ley 599 de 2000) en el que se incluyeron algunos conceptos de la teoría de la imputación objetiva, y el código procesal penal (Ley 600 de 2000) en el que se implementó un sistema mixto, en abandono del inquisitorio.

La ira, el enojo, el enfado, la inconformidad y la frustración de cara a la justicia o, mejor aún, a los jueces por ser quienes

\footnotetext{
12 NARANJO GIRALDO, Gloria. "Podría afirmarse entonces que el desconocimiento, la indiferencia y el silencio que cubren esta catástrofe humanitaria en Colombia -además de intereses innegables por encubrirlo- tiene que ver con su complejidad y diferenciación que no permiten inscribirlo en los modelos interpretativos vigentes y que lo hace irreductible a otras experiencias contemporáneas como las de los Balcanes, la Europa Oriental, el África Central y los más recientes de Timor Oriental y Chechenia" en http://www.ub.edu/geocrit/ sn-94-37.htm, fuente consultada el 23 de febrero de 2018.
} 
profieren las decisiones que suelen encarnar ese valor o ideal (justicia), han sido unos sentimientos constantes en mi país durante los siglos posteriores a la independencia patria, quizás porque dejamos de atribuirle a la divinidad o a los hijos de la Corana Española las nefastas consecuencias que se generan por una decisión infundada y alejada de la realidad social, producto de los sentimientos viscerales o de las más cruentas emociones, alejadas de la objetividad, de la razón y de la imparcialidad que de ésta se espera; expectativa defraudadas por demás desde tiempos pretéritos que popularizó aquella frase que reza: "Aqui sólo hay justicia para los de ruana".

Así, entonces, el presente escrito tiene como propósito indagar las posibles causas o razones por la que fuimos/somos receptivos a la teoría de la imputación objetiva en Colombia; así como, reseñar unas cuantas heridas de muerte causadas por la jurisprudencia a la dogmática jurídico-penal, mismas que motivan este réquiem.

\section{La dogmática penal en los tiempos de cólera}

El derecho penal sin lugar a dudas es violencia simbólica. El proceso penal desata ira, enojo, enfado, inconformidad y frustración tanto en los sujetos procesales (Fiscalía, Defensa, Víctima, Juez) como en la sociedad expectante, sentimientos que pretendo condensar en la palabra: cólera. Más allá de la licencia que la Real Academia Española me concede para hacer uso de esa palabra, pues tan solo los primeros tres sentimientos prenombrados se encuentran contenidos en ese vocativo, el último le evoco desde la magistral obra literaria "El amor en los tiempos del cólera”, escrita por Gabriel García Marqués, la cual, en mi criterio, logra retratarnos de cuerpo entero a los colombianos.

Colombia vivió cuatro décadas de violencia desatada por la acción simultánea de las guerrillas, el paramilitarismo y los narcotraficantes disputándole al Estado el monopolio del uso de las armas y la explotación agraria, minera, aurífera, entre otras fuentes de riqueza que posee mi país. La inerme población 
civil fue victimizada por los prenombrados tres actores y revictimizada cuando la judicatura no logró sancionar a quienes habían violentado sus bienes jurídico- penalmente tutelados.

Para la segunda mitad de la década de los 80`s y principios de los 90’s el panorama no podía ser más desolador. Empecemos por detallar que en 1981 el presidente de la Sala de Casación Penal de Corte Suprema de Justicia, el magistrado Alfonso Reyes Echandía, había expresado su reticencia a adoptar la teoría del finalismo, una tesis que se observaba como "novedosa" para aquel entonces. Con su muerte en el año de 1985, dado que fue una de las mentes brillantes ${ }^{13}$ inmoladas en la toma y la retoma del Palacio de Justicia de Bogotá D.C, la jurisprudencia "viviente" comenzó a dar tumbos entre el causalismo y el finalismo.

Respecto a ese tópico resulta ilustrativa la sentencia proferida el 11 de noviembre de 1986 por esa Corporación judicial. En esa oportunidad el interrogante que formularon los sujetos procesales hacía referencia a "si el hecho de que el sindicado baya expedido dos autos calificatorios, violatorios ambos en forma manifiesta de la ley, constituía uno o varios delitos» ${ }^{14}$.

13 "El asalto del M-19 a plena luz del día en la Plaza de Bolívar, a pocos metros del Congreso y del palacio presidencial, estremeció a los colombianos que durante 28 horas asistieron horrorizados a la acción guerrillera y posterior recuperación a sangre y fuego del edificio que fue pasto de las llamas y reducido a escombros.

El objetivo del comando de 35 miembros del M-19, que al mediodía del 6 de noviembre penetró disparando en el palacio y tomó como rehenes a más de 300 personas entre magistrados de la Corte Suprema y del Consejo de Estado, empleados y visitantes, era hacer un "juicio político" al entonces presidente colombiano, Belisario Betancur (1982-1986).

La Comisión de la Verdad que investigó los hechos concluyó en su informe de 2009 que "todo indica que hubo conexión del M-19 con el cartel de Medellín para el asalto al Palacio de Justicia" como parte de su guerra contra la extradición.

En el saldo trágico, además de los muertos y once desaparecidos, se cuenta la pérdida para la justicia de una generación brillante de juristas que integraban la Corte Suprema." Fuente consultada: http://www.elcolombiano.com/colombia/la-toma-del-palacio-de-justicia-unaherida-sin-cerrar-Al3028417

14 Como atinó a indicárnoslo el magistrado Jaime Giraldo Ángel, quien fue uno de los que aclaró el voto respecto de la decisión mayoritaria relievando la importancia de abordar con 
Sin embargo, el problema jurídico se esbozó en los siguientes términos:

«Se ha dado a entender, por la instancia y la Delegada, que la decisión que debe dictarse depende del criterio que se tenga acerca de cuál de las formulaciones de la teoría del delito fue la consultada por nuestro Código Penal. Doctrinariamente se plantea si tiene él una inspiración o proyección causalista inmodificable o si, citando menos, admite la posibilidad de interpretarlo bajo la estructura universalmente conocida como de la acción final o de la teoría de la acción final."

El sólo planteo lograba poner en evidencia la confrontación que existía entre los juristas formados bajo los postulados que enunció Franz Von Liszt (causalistas) y los que recibían con beneplácito las enseñanzas de Hans Welzel (finalismo), más allá de los aciertos o desaciertos de aquellos o de éstos en sus fundamentos, los cuales, es importante señalar, fueron sintetizados magistralmente por el ponente de esa decisión, así:

«2. El fundamento de la primera posición [, esto es, de la tesis causalista] se contrae a los siguientes razonamientos: (...)

No fue, pues, inopinada la consagración de la causalidad, siendo que, como se afirmó en la relación explicativa del proyecto del Código Penal de 1979, por el Presidente de la comisión, "no se tomó partido en torno a la controversia suscitada por Welzel con su teoría de la acción finalista, no sólo porque todavía su evolución doctrinaria no ha culminado, sino porque los antagonismos conceptuales son abora más agudos";

(...)

3.- A. su turno, él sustento de la segunda posición doctrinaria, [es decir, de la tesis finalista] sería:

(...)

fundamentos sólidos el planteamiento del problema jurídico y aplicar criterios de interpretación normativa que restablecieran el derecho penal mínimo. 
c) Que es incuestionable -lo admiten finalistas y causalistas, actualmente- que el fundamento de la acción es la voluntad y que no puede existir aquélla sin tal fin específico, pues, de lo contrario, no existiría voluntad y, por tanto, si la voluntad es final, asi debe tomarla el legislador. (...)

f) Que carece de fundamento la crítica respecto a que esta posibilidad interpretativa no tiene sentido, porque de una parte, el "código es causalista y, de otra, por cuanto se estaría creando un nuevo Código Penal.

En efecto, el legislador no puede establecer por ley la estaticidad del derecho, obligando al intérprete a afiliarse a una determinada tendencia o a la que pretendieron exactamente los comisionados. No hay que olvidar la experiencia histórico-jurídica: en el siglo pasado, en Alemania, ante el Código Penal causalista, cuando ni siquiera se vislumbraba el finalismo al momento de elaborarse el estatuto, la doctrina terminó construyendo la teoría finalista de la acción, no para solucionar únicamente los problemas interpretativos de ese pais, como suele equivocadamente afirmarse sino porque se consideró que la posición causal carecía de razón al explicar los fenómenos jurídicos. Esta misma concepción viene teniendo eco en otros países como Argentina. Y, esa, experiencia histórica es más reciente y elocuente en nuestro país: ante el Código Penal como el del 36, fundamentado en las tesis bio-psicológicas italianas, los doctrinantes elaboraron la teoría técnico-jurídica del delito, cuando la verdad es que ese estatuto no fue ideado bajo esa tendencia, pues aún en nuestro país ni siquiera se comentaba tal posición."

¡Admitámoslo, el causalismo hechiza! Su encanto radica en que logra ofrecer, aún en la actualidad, una explicación simplificada de cualquier fenómeno (léase: todo hecho modificador del mundo exterior) al contraerlo a la siguiente formula binaria: causa- efecto. A la acción se le concibe como un producto causal y mecánico. Al delito como un acto humano culpable, antijurídico y sancionado con una pena. 
Se distingue entre la fase interna y externa del delito. A la primera etapa se le acuñó la ideación, deliberación y resolución; mientras que a la segunda se le achacaron los actos preparativos y de ejecución.

Desde el prisma de la teoría causal, esto es, desde una perspectiva científico-naturalística se hace pasar todo hecho modificador del mundo exterior por el tamiz de las leyes de las "ciencias exactas" con el objeto de dar respuesta al porqué se produjeron esos sucesos y cuáles razones, por el contrario, no pueden explicarlos.

El positivismo jurídico supo sacar provecho entre los siglos XVIII y XIX de ese halo de las leyes físicas y de la naturaleza para posicionarse como la escuela del derecho penal que mejor cumplía los principios de justicia e igualdad.

Empero como bien reza el coro de una bella melodía: "todo llega a su final" 15 , fue al interior de la mismísimas "ciencias exactas" que la certidumbre pasó a cuestionarse con la teoría de la relativización. Y una vez erosionados los cimientos, los pilares o los fundamentos de los dogmas sobre los que el causalismo (positivismo jurídico) fundaba la responsabilidad penal de los ciudadanos, el finalismo llegó a ofrecer sus respuestas. Como bien lo expresa CORCOY BIDASOLO:

"el "conocimiento del desconocimiento de las leyes físicas" que subsiste pese a los grandes avances científicos, o mejor debido a ello, supuso la crisis del positivismo jurídico y, de ello se derivó así mismo, que el derecho penal pusiera en duda la validez de la relación causal, entendida como nexo naturalístico entre conducta y resultado, como fundamento de atribución de responsabilidad $»^{16}$.

El finalismo, por su parte, deslumbraba a quienes le conocen. Y cómo no hacerlo si la piedra de toque de esta teoría

\footnotetext{
15 https://www.youtube.com/watch?v=sFg-GLEGySI

16 CORCOY BIDASOLO, MIRENTXU. "Imputación objetiva y principio de lesividad", Revista Argentina de Derecho Penal y Procesal Penal Número 1. Noviembre de 2011. Fuente de consulta: http://www.ijeditores.com.ar/articulos.php?idarticulo=47797\&print=2
} 
consistió en señalar que la acción debía considerársele siempre con una finalidad. Ese dato, esa novedad en el planteamiento de Welzel nos citó a dar un giro copernicano.

De repente al hombre se le humanizó, si se me permite usar ese vocativo para significar que al destinatario de la norma penal se le reconoció como un ser racional al tiempo que sensible a los infortunios, en contraposición y en abandono de la tesis bio-logicista del delincuente nato o, incluso, sobre las que lograron identificar al delincuente como "el desviado" o "el degenerado" ${ }^{17}$.

Acción sólo sería aquel actuar consciente en función de un resultado propuesto voluntariamente; ergo, el resultado debía ser el exigido por el tipo penal, que ya no el meramente naturalístico.

Ese concepto de acción- final trascendió a cada uno de los elementos del delito que heredó de causalismo, esto es: la tipicidad, la antijurídica, la culpabilidad haciéndolos variar en su contenido. Verbigracia, a la categoría de tipicidad se trasladó el dolo (conocimiento y voluntad) y la culpa (imprudencia), que se les analizaba en la sede o casilla de la culpabilidad, quedando en ésta última prenombrada el elemento que se denomina "conocimiento de la antijuridicidad", en la cual, a su vez, se analizaba el desvalor de acción y el desvalor de resultado, de allí que al dolo en la tipicidad se le denomine: dolo avalorado.

Retornando a la precitada decisión de la Corte de 1985 , relevante es precisar que tuvo dos aclaraciones de voto ${ }^{18}$, los

17 En Europa los criminólogos y psiquiatras con teorías bio-logicista u organicista, centradas en la herencia y en la constitución física y psicológica del delincuente, elaboraban test mentales para medir la inteligencia y otros rasgos de la personalidad los prisioneros. Una vez realizadas estas medidas se contrastaban con la media de la población considerada normal y se estudiaban "las desviaciones" a la media. Sin que podamos olvidar que el concepto de degeneración, el cual hunde sus raíces en la obra del psiquiatra francés Morel, reenvía a las patologías de la herencia.

18 Así, por ejemplo, uno de los togados en su aclaración de voto afirmó: " $Y$ es que la finalidad del Derecho Penal es la de tratar de combatir el delito, castigándolo, previniéndolo, y resocializando a quienes han delinquido. Por eso el Código Penal en su artículo 12 dice: "La pena tiene función retributiva, preventiva, protectora y resocializadora". Las normas penales 
cuales nos permiten entrever que el debate librado entre los adeptos al causalismo y al finalismo en realidad no era más que una falacia de oposición, mediante la cual se reflejó los altos grados de insatisfacción que suele generarse cuando ninguna de las teorías del derecho penal logra colmar los intricados interrogantes que se formulaban ante las instancias judiciales y la impunidad gana todas las partidas al lograr poner en jaque la dogmática penal que hasta ese momento se conocía o, al menos, la que aceptábamos conocer, máxime cuando en un juego de "egos" todos, salvo uno, son perdedores.

Podría decirse, incluso, que esa efervescencia se disipó desde sus comienzos, y que de la referida disputa nadie se acuerda actualmente, salvo quienes desean revivirla para enfrentar a las escuelas del derecho penal que estén en boga.

Así, entonces, en la actualidad la pregunta que se formula es si la legislación penal vigente (Ley 599 de 2000) tiene una marcada tendencia al finalismo o al funcionalismo. ¡Empero que la verdad sea dicha! Se trata de una pregunta sugestiva, pues quien formula el interrogante de antemano ha logrado establecer si el togado o el juez que profirió una decisión con

\footnotetext{
deben, por consiguiente, interpretarse en función de estas metas, y de los medios que en cada caso es necesario emplear para alcanzarlas, lo que implica una permanente referencia a la realidad concreta para definir tanto la naturaleza de los fenómenos regulados, como el contenido empírico de los fines y de los medios, según las condiciones témpora- espaciales en que ellos se dan. Desde el punto de vista de los hechos, éstos no pueden considerarse corno abstracciones normativas sino como realidades concretas: El delito es un comportamiento humano que se da dentro de circunstancias de tiempo, modo y lugar, y por ciertos motivos, que es necesario conocer para poder juzgarlo. Desde el punto de vista de los fines, su contenido va cambiando con el desarrollo progresivo de los pueblos: El ideal de justicia de finales del siglo pasado, cuando se definió nuestra actual estructura jurídica, estaba cargado de connotaciones individualistas propias de la época, mientras que el de hoy está fincado fundamentalmente en un cúmulo de reivindicaciones sociales. Desde el punto de vista de los medios, hay que juzgar cada norma como un instrumento cuya adecuación al fin varía según las distintas condiciones de tiempo, modo y lugar en que se vaya a aplicar: La privación de la libertad puede ser un mecanismo eficaz para lograr la represión del delito cuando se trata de delincuentes que actúan sin ninguna constricción social o económica que los conduzca a ello, pero puede ser absolutamente contraproducente cuándo se trata de personas que sólo encuentran en el delito el único medio que la sociedad les ha dejado para atender a su subsistencia."
} 
la que está en desacuerdo es adepto a alguna de esa teorías, para arrogarle a éstas los desaciertos en que se haya incurrido en esa providencia, cuando en sana lógica todos sabemos, al menos así lo pensamos "a puerta cerrada"19 o "de dientes para adentro", que los principios doctrinales per se no conducen a una respuesta correcta o cierta (léase, que se compadezca con la realidad o la verdad de los hechos objeto de investigación penal), toda vez que éstos sólo pueden ser validados en la práctica por un buen intérprete, dado que no son más que dogmas que buscan racionalizar y objetivar esa realidad que funcionario judicial con gran esfuerzo desea aprehender (léase, agarrar, asir o coger), reconstruir como si tratara de armar unas piezas de un rompecabezas, hacerla comprensible y, entonces, aprenderla por medios de los sentidos. Empero, de esto hablaré con mayor detalle en el ítem siguiente (punto 2) de este ensayo.

La dinámica bélica y violenta en que se desarrolla la realidad cotidiana en Colombia ha logrado imponer que la judicatura realice su labor a marcha forzada. Jamás desde el interior de la rama judicial se nos ha permitió reflexionar y sopesar los beneficios ni, menos aún, los perjuicios de implantar modelos jurídicos foráneos al ordenamiento normativo interno.

Ergo, la jurisprudencia de Colombia ha terminado naturalizando los postulados tanto del causalismo como del finalismo, casi al mismo tiempo, que los del funcionalismo, sin mayor análisis y distinción entre uno y otro.

Al punto que suele observarse la aplicación simultánea en sentencias y en autos de los postulados de las prenombradas teorías del derecho penal, sin importar que sus planteamientos sean contradictorios, excluyentes o, peor, aun si se les yuxtapone. Como quien se atiborra de platillos exquisitos, mezclando bondadosas porciones de uno y otro en su boca, los deglute sin deleitar y distinguir cada uno de los sabores, porque poco o nada le importar morir indigestado.

19 Dicho popular colombiano. 
Esto es, parafraseando a Gabriel García Márquez, una "crónica de una muerte anunciada" a la dogmática penal que podríamos llegar a entender, si acaso, en "cien años de soledad", es decir, en una lógica Macondiana. Y aun así, resulta incompresible para quien nació y creció en "Zona Roja”, que fue el rotulo que se le dio al departamento del Huila por décadas por la presencia de las FARC, los grupos paramilitares y el narcotráfico; tres grupos armados al margen de la ley disputándose la hegemonía de 19890 kilómetros cuadrados de que conforman el "pasillo de la droga" ${ }^{20}$, con efectos devastadores para la población civil. Desde el secuestro, masacre, homicidio y tortura del político adinerado, del profesor de universidad pública con "ideas de izquierda", hasta el hurto de gallinas al campesino paupérrimo, sin contar los "falsos positivos" (homicidio y desaparición forzada), los delitos sexuales y los ilícitos que generaron daños irreparables (deforestación y contaminación de las aguas por voladuras de

20 El departamento del Huila está ubicado al sur de Colombia, sobre la cordillera de los Andes. Es un territorio que a más de ser boscoso, es una tierra fértil para el cultivo de la hoja de coca y amapola. Dos factores que facilitaron a la "columna móvil Teófilo Forero de las FARC" ocultarse de las autoridades del Estado de Colombia por décadas e ingresar en una cadena de producción y comercialización de cocaína y de sustancias derivadas, V.gr. bazuco, luego de que el "auto-abastecimiento" (léase, extorsión y hurto al gamonal o cacique o campesino) no les resultó suficiente. El tercer factor, por el que bien podría recibir la denominación de "pasillo de la droga" es la privilegiada posición geográfica del departamento del Huila, toda vez que al oeste colinda con los departamentos de Nariño y Putumayo, los cuales conectan con Ecuador y Perú. Mientras aquel país es bien conocido por el benévolo tratamiento punitivo a "las mulas de las drogas" (al respecto ver: www.elcomercio.com/ actualidad/correa-indulto-mulas-droga-sentencias.html), de éste (Perú) se sabe actúa como puerto o conexión para el tráfico de estupefacientes hacia oriente y, finalmente, a Europa. Agréguese, que el departamento del Huila al este limita con Caquetá, que fue el territorio designado como "zona de distención" por el gobierno de Andrés Pastrana en el año de 1998 al 2002 para significar que la Fuerza Pública (Policía Nacional y Ejército de Colombia) no operaría allí mientras se adelantaban los diálogos de Paz con las FARC. Esa decisión gubernamental permitió se exacerbaran todas acciones delictivas anteriormente descritas en la prenombrada entidad territoral, incluido el secuestro extorsivo, homicidio, tortura y otras acciones delictivas que se realizaban en perímetro opita (huilense), a sabiendas de que iban a quedar impunes porque se dificultaría su persecución al huir a la zona de distención. Ver al respecto: http://www.eltiempo.com/archivo/documento/MAM-684002 
oleoductos ${ }^{21}$ ) a los recursos naturales de esa "tierra linda que mi vio nacer" 22 , como dice la canción "Al Sur" del compositor Jorge Villamil.

Retornado al tema objeto de análisis en el presente ensayo, necesario es precisar que entre la décadas de los setentas (70` $\mathrm{s}$ ) y noventas (90`s), al interior de las universidades públicas y privadas de Medellín y Bogotá D.C. comenzaron a adoctrinarse a un grupo reducido de jóvenes estudiantes en los postulados de las escuelas del derecho penal alemán, entre éstas, por supuesto, ya se contaba el funcionalismo, gracias a los aportes de las enseñanzas de los maestros José Nodier Agudelo Bentancur y Fernando Velásquez Velásquez.

"El concepto jurídico penal de acción" tación objetiva empezó a ganar adeptos por su capacidad de restringir normativamente el tipo penal, al plantear, verbigracia:

"la representación subjetiva del resultado sólo es relevante en el plano de la comunicación si está basada en un esquema de interpretación comunicativamente relevante... Este esquema de interpretación comunicativamente relevante al que me refiero no es un mero derivado de la relación de causalidad y de la finalidad. De ningún modo se le atribuye a un ser humano como su toma de postura o como su expresión de sentido todos los cursos derivados de un comportamiento, sean finales, se hayan previsto o fuesen previsibles. Al contrario, esa atribución sólo se produce si el comportamiento de la persona se entiende como condición determinante (...) De la densa e inabarcable red de condiciones de un suceso, el esquema social de interpretación destaca - de no ser así no podría aportar nada a la orientación en el ámbito de la interacciones- ciertas relaciones como

\footnotetext{
21 "Los ríos que las FARC pintaron de Negro", publicado por Resistencia democrática, ver en: www.resistenciacivildemocratica.org/terrorismo/terror15jun.php

22 https://www.youtube.com/watch?v=EN1iqWOFIU

23 JAKOBS G, El concepto jurídico penal de acción, Editorial UNIVERSIDAD EXTERNADO DE COLOMBIA, 1996. ISBN 958-616-232, página 26.
} 
determinantes, mientras que... en el ámbito jurídico penal, esto significa lo siguiente: esa causa no genera un riesgo desaprobado. ${ }^{24}$ (Subrayas fuera del texto original).

Una década después, las disquisiciones académicas respecto al precitado postulado de la teoría de la imputación objetiva que se desarrollaban en las aulas de clase se trasladaron a la jurisprudencia, pues los jóvenes estudiantes de aquel entonces ya habían crecido, ahora litigaban ante las altas Cortes y apelaban porque las respuestas a las problemáticas que formulaban se concedieran en clave del funcionalismo, en esa jerga que le es tan propia a esta doctrina.

\subsection{La historia de cólera antes de la expedición de la Ley 599 de 2000}

La década final del siglo XX, tal como lo reseñaba en el preámbulo de este ítem, estuvo marcada por un escalamiento de la violencia de tres actores: guerrilla, autodefensas, narcotráfico, los cuales elevaron de manera exponencial (a la enésima potencia) la apertura de causas judiciales, lo cual, como es lógico, generó una congestión superlativa del sistema judicial.

Podría decirse que nos "venía a bien" otro filtro, que requeríamos de otra válvula de escape. Incluso ese vocativo fue acuñado por el mismísimo GÜNTHER JAKOBS al afirmar lo siguiente:

"la imputación objetiva elimina a modo de filtro todos aquellos comportamientos que no perturban socialmente... lo que queda es lo que crea riesgos no permitidos, esto es, lo que causa un lesión de la vigencia de la norma en caso de concurrir evitabilidad y culpabilidad... en el marco del concepto de acción que aquí se defiende, unicamente son relevantes actos que responden a unas determinadas características. Desde el punto de vista del

\footnotetext{
24 JAKOBS G, El concepto jurídico penal de acción, Editorial UNIVERSIDAD EXTERNADO DE COLOMBIA, 1996. ISBN 958-616-232, página 26.
} 
Derecho Penal, la acción siempre y en todo caso sólo es algo socialmente inadecuado ${ }^{25}$

Ahora, al comenzar el nuevo siglo, con el funcionalismo debía auscultarse si se trata de un comportamiento jurídicopenalmente desaprobado aquel hecho denunciado que, aparentemente, revestían las características de un delito de cara a la descripción típica prevista en la legislación penal.

Verbigracia, tratándose de una conducta desplegada por un ciudadano bajo los presupuestos de una legítima defensa, en manera alguna, bajo el prisma del funcionalismo, se justifica desgatar a la administración de justicia adelantándole una investigación al autor de tal comportamiento jurídicamente aprobado por la legislación penal desde antaño, menos aún requiriéndose su preclusión ante el juez de conocimiento, pues se trata de un comportamiento que se imputa positivamente, por tanto ese evento se haría merecedor de una orden de archivo por atipicidad. Empero, el análisis detallado de este tópico lo difiero al siguiente ítem (al punto segundo del presente ensayo).

Dicho de otro modo, Colombia codiciaba un nuevo sistema de selección (léase, filtro) para adelantar la persecución penal de ciertos comportamientos, pues resultaba un imposible hacerlo respecto de todos los hechos que se denunciaban. Eso justamente fue lo que nos ofreció la teoría de la imputación objetiva: un nuevo filtro, cuyos componentes suelen esbozarse en sede de tipicidad así: (i) creación de un riesgo típico (riesgo desaprobado). Es decir, de aquellos que se describen y se desean evitar desaprobar en los tipos penales; (ii) relación de riesgo. Esto es, que el riesgo creado sea el mismo que explica el resultado y; (iii) que el resultado esté cubierto por el fin de protección de la norma.

Y es que en la teoría de la imputación objetiva, para que un resultado sea objetivamente imputable a una conducta se

\footnotetext{
25 JAKOBS G, El concepto jurídico penal de acción, Editorial UNIVERSIDAD EXTERNADO DE COLOMBIA, 1996. ISBN 958-616-232, página 50.
} 
requiere, además de la relación de causalidad, que la misma haya creado un riesgo jurídicamente desaprobado y ese riesgo se haya realizado en el resultado, entendido este último en un sentido normativo y no exclusivamente naturalístico.

En síntesis, el ingreso de la teoría de la imputación objetiva en la jurisprudencia de Colombia estuvo marcado por un ambiente colérico, convulsionado por la violencia y sobresaturado por la apertura de gran cantidad de investigaciones de hechos que no revestían las características de un delito.

La Corte Suprema de Justicia de Colombia, en principio, aplicó los principios de esa doctrina para resolver una constelación de casos de delitos imprudentes y, posteriormente, a eventos de conductas dolosas ${ }^{26}$.

$\mathrm{Al}$ respecto, resulta ilustrativo la consideración consignada en SP17436-2015 lo siguiente:

"la teoría de la imputación objetiva, entendida como el método que permite establecer el "núcleo de la acción penalmente relevante", es aplicable tanto al delito imprudente como a conductas dolosas, aun cuando prima facie se le relacione con aquel, debido principalmente a que el primero de sus elementos, valga decir, la creación de riesgos jurídicamente desaprobados "se la asimila frecuentemente a un concepto que como el deber de cuidado fue originalmente ideado como requisito propio del delito imprudente"”

Así, entonces, tenemos que algunos casos de homicidio imprudentes que habían tenido lugar en quirófanos fueron los que permitieron despuntar en el derecho pretoriano colombiano conceptos tales como: (i) principio de confianza, (ii) riesgo jurídicamente desaprobado, en oposición al riesgo permitido, esto es, el que está dentro de los límites de la lex artis.

26 El concepto de infracción/violación del deber objetivo de cuidado es un requisito que también es propio de los delitos dolosos, solo que en éstos (delito doloso) con frecuencia es tan claro y evidente aquel (infracción objetivo de cuidado), que rara vez los sujetos procesales (Fiscalía, Defensa, Víctima, Juez) se detienen a verificar si el comportamiento comporta un riesgo jurídicamente desaprobado. 
La sentencia proferida el 24 de octubre de 1995 por la Sala de Casación Penal de la Corte Suprema de Justicia de Colombia fue una de las primeras en las que se aplicó el concepto de riesgo permitido. En esa oportunidad se analizaron los siguientes presupuestos fácticos:

Paciente de 30 años de edad, que se aquejaba de dolencias estomacales, remitida interconsulta especializada al médico gastroenterólogo, quien al observa en una ecografía la presencia de un tumor en el hígado, programó una biopsia incisional guiada por laparoscopia, maniobra fue abortada antes de poder tomar una muestra del tejido afectado al presentarse "vascularización». Ante la imposibilidad de la biopsia incisional, el médico especialista decidió operar al día siguiente, con el fin de extraer o "reseccionar" el tejido patogenizado, intervención que empezó en horas de la mañana. Apenas fue escindido el tumor y cuando empezaba a suturar, se origina una gran hemorragia que privó al corazón del volumen necesario de sangre (hipovolemia), lo cual generó el correspondiente paro cardíaco que ocasionó la muerte a la paciente, no obstante los esfuerzos que se hicieron para reanimarla, fallecimiento que ocurrió aproximadamente a la nueve de la mañana de aquel día.

En el fallo se relieva, lo siguiente:

«El gastroenterólogo resolvió realizar la referida operación sin la obtención, especialmente, de una arteriografía o angiografía, examen de rigor en casos como el que se acaba de narrar y que permite establecer el mapa de la irrigación sanguínea en el área objeto de intervención. ${ }^{27}$

Y en la parte considerativa se dijo:

"Si lo programado como se insiste fue una biopsia, no ha debido llegarse a la resección tumoral sin el consentimiento del paciente, y sin las cautelas médicas previas que indica la lex artis. Con el procedimiento

27 CSJ, SP 24 de octubre de 1995, radicado 9651. 
contrario, sin duda, se incurre en la creación de un riesgo no autorizado por el paciente, para el cual, además, no se contaría con la preparación del intervenido, ni la del campo de acción quirúrgica” ${ }^{28}$

Habría de destacarse de la precitada decisión que los postulados de la teoría de la imputación objetiva no fueron aplicados para resolver vacíos probatorios o falencias procesales.

Es decir, en ese caso no se trató de sustituir la causalidad, entendida aquí desde su perspectiva procesal como prueba de los hechos que son objeto de la acusación ${ }^{29}$, por los conceptos de riesgo jurídicamente desaprobado y principio de confianza.

Igualmente, es de relievar que ese caso versó sobre el tipo penal de homicidio culposo, esto es, un delito de resultado. Al respecto, huelga recordar que en el funcionalismo, al menos en su tesis mayoritaria, suele separarse la categoría la causalidad y la imputación, salvo cuando el análisis se hace versar sobre los delitos de resultado.

Esa excepción tiene la siguiente explicación: la consumación de la acción punible es un presupuesto necesario para poder establecer si se ha realizado el resultado típico, por tanto, a la acción y al resultado no se les separa al momento de abordar el análisis del caso en particular porque es necesario que el resultado se le pueda imputar al autor como el producto de su comportamiento.

Ahora bien, ello en manera alguna puede significar que tras verificarse la relación de causalidad (nexo causal) entre una determinada conducta respecto al resultado tipificado se pueda acceder per se a tener por demostrada la responsabilidad penal (léase, vínculo normativo) del autor de ese comportamiento y, por tanto, que sólo bastara con definir si se trató de una acción culposa o dolosa. No, se itera, puede el dogmático jurídico

\footnotetext{
28 Magistrado ponente: Fernando Arboleda Ripoll.

29 CORCOY BIDASOLO, MIRENTXU. "Imputación objetiva y principio de lesividad", Revista Argentina de Derecho Penal y Procesal Penal Número 1. Noviembre de 2011. Fuente de consulta: http://www.ijeditores.com.ar/articulos.php?idarticulo=47797\&print=2
} 
penal del siglo XXI llegar a una resolución tan facilista como la planteada, menos aún de cara a los postulados del funcionalismo, con precisión, de la teoría de la imputación objetiva, pues ésta nos enseña que luego de verificarse el nexo causal entre una conducta humana y el resultado típico, verbigracia (lesiones personales), continua estando latente interrogarnos si aquella se trató de una acción jurídicamente desaprobada (riesgo no permitido) en ese contexto social; ergo, relevante para el derecho penal de esa comunidad, toda vez que las normas de conducta en que se basan las tipificaciones penales no se dirigen contra cualquier acción sino, en exclusiva, se persigue aquellas "que no se encuentran en el marco del riesgo permitido o que sobrepasan la medida de dicho riesgo"30.

No obstante, debe reconocerse que no siempre se ha aplicado en la jurisprudencia de Colombia de manera atinada los postulados de la teoría de la imputación objetiva, ni menos aún de las teorías de la dogmática jurídico-penal que le antecedieron, esto es, del finalismo y causalismo.

Dentro de los desaciertos más evidentes se encuentra la sentencia del 10 de julio de 1997, radicado 9781, pues en ella se habla de con-causalidad al tiempo que de la teoría de la equivalencia de las condiciones, desconociéndose que ésta excluye aquella.

El epicentro del análisis se basó en la siguiente idea:

"El fenómeno de concurrencia de riesgos, o con-causalidad, ha sido uno de los temas más complejos a través de la dogmática jurídico penal. De acuerdo con dicha figura, en la realización del resultado intervienen varios cursos lesivos, los cuales pueden ser producto de la acción de un tercero o por la propia víctima, esto último en especial cuando infringe sus deberes de auto protección. (...)

30 LOPEZ DIAZ, CLAUDIA. "Introducción a la imputación objetiva". Colección de estudios No. 5. Universidad Externado de Colombia. Centro de Investigaciones de Derecho Penal y Filosofía del Derecho. Página 23. 
Si de conformidad con los lineamientos básicos de la teoría de la imputación objetiva -como viene de verse- o de otros esquemas dogmáticos bajo la óptica del instituto de la con-causalidad, en caso de confluir varios cursos lesivos del bien jurídico de un tercero la solución está orientada hacia la responsabilidad conjunta de los autores, no parece apropiada, en principio (...) En orden a establecer la conexidad entre el riesgo y el resultado producido, la teoría de la imputación objetiva ha diseñado mecanismos en la mayoría de las veces de gran utilidad para su determinación apelando a los denominados cursos causales hipotéticos, conforme a los cuales se asume que aún frente a un comportamiento diverso del autor la consecuencia en todo caso se hubiera producido, básicamente porque "un re*sultado no puede serle imputado al creador de un riesgo jurídicamente desaprobado si dicho resultado se bubiere producido incluso con una conducta diversa del autor", problemática que conduce a confrontar esta situación con la inevitabilidad del resultado." (Subrayas fuera del texto original).

Empecemos por señalar que la teoría conditio sine qua non (teoría de la equivalencia de las condiciones) no efectúa ninguna selección entre innumerables condiciones porque considera que todas ellas tienen idéntico valor. Esa es la razón por la que no puede hablarse de "con-causas", en tanto que ninguna condición predomina sobre las restantes. De otra forma dicho, todas son igualmente causales.

Lo que si resulta apropiado bajo los principios de esa doctrina es reconocer la existencia de nuevo curso causal. Al respecto ROXIN nos dice:

"falta la relación causal cuando una cadena ya iniciada es sobrepasada por otra que le impide continuar actuando, y por lo tanto ya no se produce la relación determinante con el resultado, ${ }^{31}$.

31 Ibídem. 
La tesis de la con-causalidad que se manejó en la precitada sentencia del 10 de julio de 1997, radicado 9781, se replicó en la sentencia del 2 de julio de 2008, radicación 28441, la que, a su vez, fue reiterada en los fallos de casación de 11 de mayo de 2005, radicación 22511; de 28 de octubre de 2009, radicación 32582; y, de 20 de mayo de 2003, radicación 16636, y de 27 de febrero de 2012, radicado 36854 .

Cada una de esas referidas decisiones guarda en sí misma una incoherencia que solo puede advertirse cuando se comprende a cabalidad que la teoría de la equivalencia de las condiciones se caracteriza porque no puede hablarse de interrupción del curso causal, pues ni siquiera la irregularidad o extravagancia de un curso causal logra romper la relación condicional ${ }^{32}$.

En sentencia del 12 de noviembre de 1999, radicado 10776, esa falencia se trata de corregir. En esa oportunidad la Corte analizó el caso de dos primos hermanos que luego de una confrontación verbal, se propinaron lesiones con arma corto- punzante, quedado uno de ellos herido en "el hemitórax izquierdo a nivel del sexto espacio intercostal, en línea medio clavicular, y la otra en el hemitórax derecho a nivel del octavo espacio intercostal, con línea medio axilar".

El herido ingresó inicialmente a un hospital, en el cual le dieron de alta unos días después; pero, en vista de la agravación del estado de salud del lesionado, sus familiares lo llevaron a otro centro de atención de servicios de salud pública, en el que fue intervenido quirúrgicamente, falleciendo tiempo después, "como consecuencia de una sepsis secundaria a complicaciones de peritonitis y empiema que produjeron las heridas".

Al proceso penal fue vinculado el familiar del occiso (el primo), quien le propinó las heridas con arma corto-punzante a éste (la víctima), en calidad de autor de homicidio simple. Durante el curso del proceso se le acusó por ese mismo cargo

32 LOPEZ DIAZ, CLAUDIA. "Introducción a la imputación objetiva". Colección de estudios No. 5. Universidad Externado de Colombia. Centro de Investigaciones de Derecho Penal y Filosofía del Derecho. Página 26. 
en grado de tentativa, "dado que la muerte de la víctima se produjo por una peritonitis que constituyó una concausa sobreviniente al mal manejo médico". El fallo de condena de primer y segundo nivel se profirió por "el punible de bomicidio simple, atenuando la culpabilidad por la ira."

La tesis mayoritaria de la Corte, en sede casacional, fue la siguiente:

"La condición de mortalidad ya estaba envuelta en la naturaleza misma de las lesiones ocasionadas, por ser penetrantes a tórax y haber comprometido el diafragma, y no apareció con el desarrollo fisiopatológico de las heridas, aunque éste indudablemente incrementó el riesgo de muerte. Esa potencialidad letal de las heridas desde el momento mismo de su irrogación, aparte de que afirma el nexo causal una vez constatada la muerte sin interferencias abruptas o extraordinarias de otros sucesos concurrentes o sobrevinientes (grave descuido técnico o incremento malicioso de las secuelas por la víctima o intervención dolosa de tercero), igualmente introduce el principio tutelar de la antijuridicidad material en el ámbito de la solución del caso, como límite a la simple causalidad, pues se exige de la conducta que per se dañe o ponga en peligro la vida como bien jurídico protegido, acorde con la idea regulativa de que la función de la norma penal es la tutela de importantes intereses jurídicos para mantener la coexistencia pacífica (art. $4^{\circ}$ C. P.).

De igual manera, la previsibilidad por parte del sujeto del riesgo de muerte de quien es lesionado con tal magnitud $y$ de las fallas corrientes en el diagnóstico y tratamiento posteriores de las heridas, así como la asunción voluntaria de lo que el individuo prevé, son manifestaciones existenciales de la exigencia del principio rector de la culpabilidad, otra limitación normativa a la mera causalidad"

El salvamento de voto a la precitada decisión es la de relievar en el presente trabajo al enfatizar en que "la relación 
de causalidad no admite interrupción", al tiempo que insinúa existió un nuevo curso causal que sobrepasó la relación causal ya iniciada. Precisó el magistrado disidente:

«Estimo, al contrario de la mayoría, que la conducta imputada no puede ser objeto de condena por el delito de homicidio pues sólo alcanzó el grado de tentativa. Las razones son las siguientes:

(...)

2. Del expediente se deduce que hubo heridas con el propósito de matar. Pero también que el lesionado, luego de ello, fue atendido, salió de la clínica u hospital con vida y que su deceso se produjo posteriormente. De esta sola circunstancia, de cara al expediente, emana que (...) hirió, lesionó a (...), y que él no le causó la muerte.

3. En la sentencia de casación, con fiel reflejo del expediente, se leen unas afirmaciones; y, de cuño ya de la Sala, se hacen otras.

(...)

De lo escrito anteriormente se extracta una afirmación indiscutible: la víctima fue herida por arma cortopunzante. Fue examinada y cuidada médicamente. Pero no lo suficiente pues bajo la convicción de que ya todo había pasado, fue dada de alta y días después devino su muerte. Y se ha establecido, y se ha aceptado por la Sala, que el médico ha debido ser más cuidadoso, que si lo hubiera sido, hasta se habría salvado la vida de don (...) y que el galeno omitió un mayor cuidado.

Es fácil entonces concluir que la muerte ocurrió no por el comportamiento de (...) sino por la conducta médica, concomitante y subsiguiente al momento de la atención por parte del experto, con independencia de que se tratara de heridas "esencialmente mortales" o "simplemente mortales" pues que, en cuanto al primer tipo, se sabe que no lo eran; y en cuanto a la segunda clase, siendo idóneas pero remediables respecto de un fatal desenlace, en este asunto parcialmente fueron soportadas y luego olvidadas. Así, el nexo causal determinante se predica 
no del autor de las heridas sino de quien hizo dejación del cuidado debido y, por tanto, en relación con aquel se rompe el vínculo causal. Así las cosas, [el aquí acusado] debería responder por lo que hizo, es decir, herir con dolo homicida, para una tentativa de homicidio porque hasta allí llegó "su" causalidad. Lo demás, el suceso final lamentable, no atribuible a él, no se le puede imputar $y$, por consiguiente, se imponía casar la sentencia. ${ }^{33}$ (Subrayas fuera del texto original).

La diferencia entre la tesis esbozada por el togado que salvó el voto y la mayoritaria adoptada por la Sala de Casación Penal de la Corte Suprema de Justicia de Colombia es tan elemental que se puede sintetizar así: La teoría de la imputación objetiva no debe asimilársela a la de la causalidad, con el propósito perverso de suplir o sustituir las falencias probatorias de ésta con los postulados de aquella; empero, menos aún debe contraponérselas.

Obsérvese como en la argumentación ofrecida en el salvamento de voto, en primer orden, se adelanta un análisis de los presupuestos fácticos de la acusación que contaban con fundamento probatorio y, por tanto, se desestimó (léase, se dejó sin valor) aquellos que carecían de soporte suasorio; para luego si, en un segundo nivel de estudio, aplicarse los postulados de la imputación objetiva.

En otras palabras, solo una vez el togado logró establecer la causalidad, entendida aquí como la prueba de los hechos que son objeto de la acusación, es que se procedió aplicar el principio de riesgo permitido y del principio de confianza, no a la inversa, como ocurrió en la tesis adoptada por la sala mayoritaria de la Corte.

Y ya para el año 2010, en sentencia del 28 de julio de ese año, radicado 33116, se logra advertir la evolución jurisprudencial respecto a la teoría pluricitada señalándose lo siguiente:

33 Magistrado ÁlVARO ORLANDO PÉREZ PINZÓN. 
«3) Si bien es cierto que la causalidad (en tanto ley, fenómeno empírico o hecho natural) ha sido cuestionada desde los albores del siglo XX en razón del desarrollo del conocimiento científico (tanto en el ámbito de las partículas subatómicas -física cuántica- como en el del cosmos -teoría de la relatividad), también lo es que ello no ha sido obstáculo para que, en la vida cotidiana, su importancia continúe vigente. Por el contrario, constituye el primer paso, necesario mas no suficiente, para efectos de atribuir el resultado previsto en el tipo como obra o consecuencia de la conducta de determinada persona.

(...)

Lo anterior implica que no toda afectación a un bien jurídico causada por el comportamiento humano tiene repercusiones penales.

(...)

En este orden de ideas, la imputación al tipo objetivo tan sólo se configura cuando, establecida la relación de causalidad, es viable predicar en el sujeto agente (i) la creación de un peligro para el objeto de la acción que sea jurídicamente desaprobado y (ii) la realización de dicho riesgo en el resultado obtenido.»

Ahora bien, es importante precisar que a finales de la década de los noventa (90`s) la jurisprudencia en Colombia también aplicó los conceptos de riesgo permitido y principio de confianza al abordar el análisis de delitos contra la administración pública cometidos por servidores públicos, donde el problema jurídico se hacía versar sobre si la conducta punible se había adelantado en la modalidad dolosa o imprudente.

Así, por ejemplo, en la sentencia del 16 de septiembre de 1997 , radicado 12655, se soslayó el estudio de los alcances o límites de esos conceptos de la teoría de la imputación (principio de confianza), forzándose a la dogmática jurídico penal para remediar las falencias probatorias y ofrecer como resultado la aplicación del tipo penal más benigno, esto es, el de peculado imprudente (culposo). 
Una docena de fallos más incluyeron los referidos conceptos de la imputación objetiva antes de comenzar el nuevo siglo, gran parte de ellos, por no decir la totalidad, referidos a conductas punibles imprudentes en el ejercicio de la profesión médica en los cuales se replicaron las consideraciones expuestas en la precitadas sentencias.

\subsection{La historia de cólera después de la expedición del nuevo código penal}

¿Y qué paso con la cita que nos había hecho el funcionalismo para que nos re-normativizáramos? Pues, bien, la cumplió el legislador en el año 2000.

Tal como lo señalé en ítem precedente, la orientación funcionalista nos citó a re-pensarnos, mejor aún, a re-normativizarnos, pues bajo esa perspectiva no es posible elaborar categorías dogmáticas con base a elementos pre-jurídicos, lo cual nos llevó a dar otro giro copernicano, cuyos efectos se volcaron en la legislación penal.

Podría decirse que para comienzos del siglo XXI se reinició la partida, teniendo el Estado como as bajo la manga: el aporte de la academia. Se expidieron dos nuevas legislaciones: el código penal (Ley 599 de 2000) y el código procesal penal (Ley 600 de 2000), las cuales se constituyeron en la apuesta más grande que el legislativo hacían para ganarle el juego a la impunidad.

En la parte general del Código Penal, Ley 599 de 2000, se ingresaron las nociones de "posición de garante", "fuente de riesgo" y otras, así:

Artículo 9 Conducta punible. Para que la conducta sea punible se requiere que sea típica, antijurídica y culpable. La causalidad por sí sola no basta para la imputación jurídica del resultado.

Artículo 25: Acción y omisión. La conducta punible puede ser realizada por acción o por omisión. 
Quien tuviere el deber jurídico de impedir un resultado perteneciente a una descripción típica y no lo llevare a cabo, estando en posibilidad de hacerlo, quedará sujeto a la pena contemplada en la respectiva norma penal. A tal efecto, se requiere que el agente tenga a su cargo la protección en concreto del bien jurídico protegido, o que se le haya encomendado como garante la vigilancia de una determinada fuente de riesgo, conforme a la Constitución o a la ley.

Son constitutivas de posiciones de garantía las siguientes situaciones:

1. Cuando se asuma voluntariamente la protección real de una persona o de una fuente de riesgo, dentro del propio ámbito de dominio.

2. Cuando exista una estrecha comunidad de vida entre personas.

3. Cuando se emprenda la realización de una actividad riesgosa por varias personas.

4. Cuando se haya creado precedentemente una situación antijurídica de riesgo próximo para el bien jurídico correspondiente.

Si la causalidad por sí sola no basta para la imputación jurídica del resultado, de conformidad con el mandato legal precitado (artículo 9 del Código Penal), entonces es importante interrogarnos ¿Qué más consideró el legislador se requiere? Parafraseando a MOLINA ARRUBLA ${ }^{34}$, es necesario verificar el cumplimiento de los postulados de la imputación objetiva para hablar de la existencia de tipicidad objetiva- subjetiva ${ }^{35}$.

34 MOLINA ARRUBLA, CARLOS MARIO. Funcionalismo e imputación objetiva en el derecho penal. Editorial Leyer, 2010.

35 Aquí es importante recordar que la teoría de la imputación objetiva requiere se constate la parte subjetiva del tipo penal. Echando mano de una metáfora, imaginémonos por un instante que estamos ante una escalera con _ peldaños. Para acceder al primer escalón debo "probar positivamente, con una probabilidad rayana en la certeza cuál ha sido el devenir de los hechos" (causalidad), atendiendo ya sea las estadísticas, las leyes de la ciencias naturales o, incluso, las sociales. Una vez se cuenta con hechos racionalmente probados, es posible ingresar al 
La nueva legislación penal parecía enviar un mensaje optimista, esperanzador para quienes acudían a la vía del Derecho con el objeto de resolver sus conflictos, en cuanto a que debían continuar propendiendo por la vigencia de norma, independientemente del concepto subjetivo de justicia que cada sujeto procesal (Fiscal, Juez, Defensor, Víctima) tuviese.

Puesto que "A una expectativa normativa no se ba de renunciar ni siquiera en casos de decepción, sino que ésta ba de mantenerse (contra-fácticamente), si como fallo decisivo no se define la expectativa del decepcionado, sino la infracción de la norma por parte del que decepciona. Ejemplo: Se encierra al malhechor para poner de manifiesto lo incorrecto de su conducta.» (JAKOBS-1995, p. 10)

Así, entonces, se abrió una especie "brecha". Se nos invitó a tomar distancia respecto a la dogmática ontologicista, y empezar a observar a la acción, la tipicidad, la antijuridicidad y la culpabilidad (como elementos de la teoría del delito) conforme con los fines y las funciones que cumple el derecho en la sociedad ${ }^{36}$

segundo escalón denominado: "presupuesto de imputación", en el cual se trata de determinar si se ha creado un riesgo jurídico-penalmente relevante como consecuencia de una conducta humana 0 si no se ha controlado un riesgo existiendo el deber de hacerlo, de forma que equivalga a su creación. Se trata de un juicio no meramente subjetivo, pues en este análisis se indagan los conocimientos que el sujeto agente tenía respecto del riesgo que estaba creando con su conducta, para lograr determinar si creó un riesgo doloso o imprudente.

36 «El contenido y la función de la pena no se puede configurar (ni siquiera limitándose a la pena estatal) con independencia de la existencia del orden en el que se pune, ni de la comprensión de su sentido. Así, por lo que se refiere a la existencia del orden, un Estado que deba concentrar sus fuerzas para el aseguramiento de su existencia (p.ej. en guerra) empleará la pena de modo que al menos a corto plazo garantice la eficacia (p.ej. intimidación por medio de penas severas), mientras que un Estado sin problemas agudos de existencia puede asumir la inefectividad a corto plazo, las miras de la paz interna (p.ej. evitando penas severas para no embotar la sensibilidad ante la violencia). Por lo que se refiere a la comprensión del sentido del orden, de ésta depende que se entienda a la pena, p. ej. Desde la teoría de conflictos, como medio de lucha de la clase dominante 0 , en general, de grupos dominantes en la sociedad, o como medio de defensa frente a pretensiones de dominio ilegítimas (o intempestivas), que hieran la espada de la superioridad guiada según ideas religiosas, 0 que el autor sea castigado por su propia voluntad, porque también él es parte del contrato social. (...) La pena es siempre reacción ante la infracción de una norma. Mediante la reacción siempre se pone de manifiesto que ha de observarse la norma. Y la reacción demostrativa 
Cobramos conciencia de que el péndulo de la historia del derecho penal se había desplazado del ontologicismo al normativismo, esto es, "de un concepto de imputación basado en criterios empíricos (teoría causal de la acción) hasta llegar a un concepto fundamentado normativamente (teoría de la imputación objetiva)" 37 .

Al respecto, resulta ilustrativa la sentencia del 26 de junio de 2013, radicado 38904, pues en ella la Corte Suprema de Justicia de Colombia consignó la siguiente consideración:

"De acuerdo con la evolución doctrinaria y jurisprudencial del delito imprudente, lo esencial de la culpa no reside en actos de voluntariedad del sujeto agente, superando asi aquellas tendencias ontologicistas que enlazaban acción y resultado con exclusivo apoyo en las conocidas teorías de la causalidad -teoría de la equivalencia, conditio sine qua non, causalidad adecuada, relevancia típica-, sino en el desvalor de la acción por él realizada, signado por la contrariedad o desconocimiento del deber objetivo de cuidado, siempre $y$ cuando en aquella, en la acción, se concrete, por un nexo de causalidad o determinación, el resultado típico, es decir, el desvalor del resultado, que estuvo en condiciones de conocer y prever el sujeto activo.

En la doctrina penal contemporánea, la opinión dominante considera que la realización del tipo objetivo en el delito imprudente (o, mejor dicho, la infracción al deber de cuidado) se satisface con la teoría de la imputación objetiva, de acuerdo con la cual un becho causado por el agente le es jurídicamente atribuible a él si con su

\footnotetext{
siempre tiene lugar a costa del responsable por haber infringido la norma (por "a costa de" se entiende en este contexto la pérdida de un bien. Se trata de un problema normativo: de la asignación a quien ha de soportar aquellos costes que son necesarios para eliminar la perturbación» JAKOBS,G. Derecho Penal. Parte General. Fundamentos y teoría de la imputación, Ed. Marcial Pons. Madrid, 1995. Página 8.

37 LOPEZ DIAZ, CLAUDIA. "Introducción a la imputación objetiva". Colección de estudios No. 5. Universidad Externado de Colombia. Centro de Investigaciones de Derecho Penal y Filosofía del Derecho. Página 19.
} 
comportamiento ha creado un peligro para el objeto de la acción no abarcado por el riesgo permitido y dicho peligro se realiza en el resultado concreto.

Lo anterior significa que si la infracción al deber de cuidado se concreta en el desconocimiento de la norma de cuidado inberente a actividades en cuyo ámbito se generan riesgos o puesta en peligro de bienes jurídicamente tutelados, es necesario fijar el marco en el cual se realizó la conducta y señalar las normas que la gobernaban, a fin de develar si mediante la conjunción valorativa ex ante y ex post, el resultado que se produjo, puede ser imputado al comportamiento del procesado.

En otras palabras, frente a una posible conducta culposa, el juez, en primer lugar, debe valorar si la persona creó un riesgo jurídicamente desaprobado desde una perspectiva ex ante, es decir, teniendo que retrotraerse al momento de realización de la acción y examinando si conforme a las condiciones de un observador inteligente situado en la posición del autor, a lo que habrá de sumársele los conocimientos especiales de este último, el becho sería o no adecuado para producir el resultado típico.

En segundo lugar, el funcionario tiene que valorar si ese peligro se realizó en el resultado, teniendo en cuenta todas las circunstancias conocidas ex post.

En aras de establecer cuándo se concreta la creación de un riesgo no permitido y cuándo no, la teoría de la imputación objetiva integra varios criterios limitantes o correctivos que llenan a esa expresión de contenido, los cuales también han tenido acogida en la jurisprudencia de la Sala :

No provoca un riesgo jurídicamente desaprobado quien incurre en una "conducta socialmente normal y generalmente no peligrosa", que por lo tanto no está probibida por el ordenamiento jurídico, a pesar de que con la misma haya ocasionado de manera causal un resultado típico o incluso baya sido determinante para su realización. 
Tampoco se concreta el riesgo no permitido cuando, en el marco de una cooperación con división del trabajo, en el ejercicio de cualquier actividad especializada o profesión, el sujeto agente observa los deberes que le eran exigibles y es otra persona perteneciente al grupo la que no respeta las normas o las reglas del arte (lex artis) pertinentes. Lo anterior, en virtud del llamado principio de confianza, según el cual "el hombre normal espera que los demás actúen de acuerdo con los mandatos legales, dentro de su competencia".

Igualmente, falta la creación del riesgo desaprobado cuando alguien sólo ba participado con respecto a la conducta de otro en una "acción a propio riesgo", o una "auto puesta en peligro dolosa".

(...)

En cambio, "por regla absolutamente general se habrá de reconocer como creación de un peligro suficiente la infracción de normas jurídicas que persiguen la evitación del resultado producido".

Así mismo, se crea un riesgo jurídicamente desaprobado cuando concurre el fenómeno de la elevación del riesgo, que se presenta "cuando una persona con su comportamiento supera el arrisco admitido o tolerado jurídica y socialmente, así como cuando, tras sobrepasar el límite de lo aceptado o permitido, intensifica el peligro de causación de daño.

Se extrae de esta cita que, más allá del solo nexo de causalidad entre la acción y el resultado, la atribución de responsabilidad en grado de culpa demanda que el comportamiento imprudente del sujeto activo de la infracción se despliegue creando o extendiendo un riesgo no permitido o jurídicamente desaprobado -en relación con las normas de cuidado o reglas de conducta-y necesariamente se concrete en la producción del resultado típico, lesivo de un bien jurídico protegido. Esto, teniendo en cuenta que en vigencia de la Ley 599 de 2000 (artículo 9"), "la causalidad por sí sola no basta para la imputación jurídica del resultado". 
En el nuevo siglo, los casos que fueron objeto de análisis ya no se limitaron a lesiones personales y homicidios culposos acaecidos en accidentes de tránsito o en los quirófanos, pues cada vez con mayor solvencia argumentativa se aplicaba a delitos contra la administración pública, las sentencias de: (i) el 19 de octubre de 2006, radicado 22354; (ii) el 28 de septiembre de 2006, radicado 24031; (iii) el 18 de enero de 2015, radicado 47100 , en las cuales se estudió la conducta delictiva de peculado con el objeto de determinar si debía atribuirse en grado de culpa o dolo, replicaron la función pedagógica que cumplió la Sala de Casación Penal de la Corte Suprema de Justicia de Colombia en la sentencia del 30 de junio de 2004, radicado 21770, de la cual cabe resaltar la siguiente consideración:

"De otra parte, las teorías sobre la causalidad y la imputación jurídica del resultado no son ajenas a las decisiones de la Corte, y en ese sentido los libelistas pasan por alto que:

“... antes y después de la vigencia de la ley 599 de 2000, han existido pronunciamientos de la sala en punto de la causalidad y como ella no basta por si sola para la imputación jurídica del resultado, en tanto que establecida la causación material del resultado, resulta imperativo por mandato legal, entender que la imputación no podrá ser simplemente causal sino que esta debe ser jurídica, en tanto se requiere tener como fuente para establecerla, la probibición típica, a la cual se impone igualmente fijarle su sentido, el cual no podrá ser abstracto sino tener en cuenta su objeto de protección, esto es el bien jurídico que con la misma se pretende tutelar y bajo tal sustento determinar si la acción objeto de análisis corresponde a la probibida, es decir si con ella se ha puesto en peligro o vulnerado el bien jurídico protegido, lo cual exige recurrir a criterios valorativo normativos que jurídico socialmente confronten la conducta en cuestión dentro del alcance típico del supuesto de hecho."”8,

38 CSJ, SP 27 de mayo 2003, radicado 19988 
Ahora bien, bosquejado el grado evolución al que supuestamente había llegado la jurisprudencia de Colombia en la implementación de una teoría de la imputación objetiva, solo me resta señalar que fue el concepto de posición de garante el que ha hecho virar en más de una ocasión la tesis mayoritaria de la Sala de Casación Penal de la Corte Suprema de justicia, al sustituirse con éste las falencias probatorias de la Fiscalía respecto al grado de conocimiento con el que contaba el acusado (sujeto agente) al momento de adelantar su conducta

Así, por ejemplo, tenemos que en sentencia del 25 de agosto de 2010, radicado 32964, la Corte por primera vez avaló la aplicación del dolo eventual en el delito de homicidio ocurrido en el tráfico automotor, pues antes de la referida fecha se le calificaba sin dubitación alguna como un comportamiento culposo (culpa con representación). En esa oportunidad se analizaron los siguientes supuestos fácticos:

Promediando las 22 y 23 horas del miércoles 22 de agosto de 2007, RSSR, piloto de profesión, con 24 años de edad en ese entonces, asistió a una fiesta de cumpleaños en el domicilio de su amiga, ubicado éste en un lugar residencial de la ciudad de Bogotá D.C, a donde llegó conduciendo la camioneta Toyota Prado gris, lugar en el cual permaneció hasta las 4 horas del jueves 23 de agosto ingiriendo licor en considerable cantidad. En el parqueadero donde había dejado estacionado su vehículo, fumó un cigarrillo de marihuana, luego de lo cual emprendió su camino tomando la avenida 19, en sentido norte- sur, sucediendo que a la altura de la calle 116, la cual atravesó con exceso de velocidad, sin obedecer la luz roja del semáforo que le imponía detener la marcha, y sin realizar maniobra alguna para esquivar el obstáculo que tenía ante sí, colisionó de manera violenta con la camioneta Nissan que se desplazaba a velocidad reglamentaria en dirección occidente- oriente por la referida calle 116, arrastrándola por varios metros, al punto de derrumbar tres postes ubicados sobre el separador y causar la muerte instantánea de sus dos ocupantes. 
Antes de citar lo considerado por la Sala de Casación Penal de la Corte Suprema de Justicia, aceptemos que la distinción entre dolo eventual y culpa con representación ni siquiera para la doctrina ha sido fácil, pues la línea divisoria es "bastante delgada", empero no invisible, toda vez que ambas formas de responsabilidad parten de una estructura común, esto es, que el autor: (i) no desea el resultado y (ii) reconoce la posibilidad de que este último se produzca. Sin embargo, esa proximidad se fractura en cuanto en la primera el sujeto confía en que el resultado no se produzca, pero en el eventual se deja librada al azar la producción o no del resultado (artículo 22 de la Ley 599 de 2000).

Entre las varias teorías formuladas por la doctrina para superar ese escollo, la jurisprudencia de Colombia seleccionó las siguientes dos: (i) La del consenso o consentimiento, conforme a la cual el elemento distintivo es la aprobación interior de la realización del resultado, esto es, que al autor consiente en la posibilidad del resultado; y (ii) La de la probabilidad, en la cual se verifica la representación que el autor se haya hecho del resultado advertido, por ende, habrá dolo eventual "cuando el autor advirtió una gran probabilidad de que se produjese el resultado" y culpa con representación o consciente si la posibilidad del resultado "reconocida por el autor era muy lejana.

Hecha tal precisión, veamos como el concepto de posición de garante fue aplicado para suplir las falencias probatorias. La Corte se vale de dos circunstancias probadas: (i) la experiencia profesional del autor de la conducta como piloto de aeronaves, y (ii) la ingesta de sustancias de alucinógenos para estructurar una verdadera falacia de petición de principio, referida al grado de conocimiento con el que actuó el sujeto agente, el que, es importante resaltar, el Tribunal de instancia, había enlistado como "hecho probado", así:

"El tribunal declaro probados los siguientes hechos relevantes:

1. Que el procesado RSSR es piloto de aeronaves comerciales y que de su proyecto de formación hizo parte una 
materia denominada "Programa de Prevención de Alcobol y Drogas".

2. Que en su hoja de vida como conductor de vehículos reporta varias órdenes de comparendo, entre las que se cuentan algunas por conductas peligrosas, como manejar a una velocidad superior a la permitida.

(...)

4. Que esa noche ingirió bebidas alcohólicas y sustancias estupefacientes. Los análisis de alcoholemia arrojaron un grado de concentración en la sangre de 181 mililitros por ciento, y los de toxicología resultados positivos para cannabis.

5. Que al abordar el vehiculo se hallaba en capacidad de comprender la ilicitud de su comportamiento y de determinarse de acuerdo con es a comprensión, y que cuando lo bizo estaba orientado y en capacidad de percibir la realidad.

6. Que al abandonar la casa de su novia tomó la avenida 19 hacia el sur y que en la intersección de la avenida calle 116 bizo el cruce encontrándose el semáforo en rojo y a una velocidad que oscilaba entre 65 y 97 kilómetros bora.

7. Que al cruzar la avenida calle 116 chocó violentamente contra una camioneta Nissan que se movilizaba de occidente a oriente por la referida arteria, causando la muerte de sus dos ocupantes.

8. Que momentos antes del impacto estuvo cerca de chocar un taxi que transitaba delante de la camioneta impactada, el cual, al llegar a la intersección de la carrera 19, giró a la izquierda, en contravía, para tomar la calle 116 en sentido contrario (de oriente a occidente).

9. Que cuando el taxista hizo el giro probibido la camioneta del procesado se hallaba a una distancia de entre 54 y 80 metros.

10. Que el taxista se bajó del vehículo y se dirigió al lugar del accidente, bajó al procesado de la camioneta que conducía, y que al interpelarlo por lo ocurrido le 
respondía con frases sin sentido, como tranquilo, que no ha pasado nada, soy bijo de Uribe; $y$,

11. Que en el lugar de los hechos no se hallaron buellas de frenada."

Las sentencias del 16 de diciembre de 2015, radicado 45008 y del 25 de mayo de 2015, radicado 45329, replicaron esa errada forma de aplicar la teoría de la imputación objetiva para sustituir la prueba de los hechos objeto de la acusación, con violación a los principios de in dubio pro reo.

\subsection{El principio de lesividad}

¿Qué se entiende por bien jurídico? Sin importar el concepto que se tenga de bien jurídico, aceptemos que éste ha cumplido una función de garantía para los ciudadanos, en cuanto a través de él pretendemos explicarles las razones del por qué el Estado se encuentra facultado para intervenir en sus vidas, en su esfera privada.

El principio de lesividad también se reafirma según el concepto que tengamos del bien jurídico, pues la intervención punitiva cobra sentido (léase, se legitima) si de protegerle (bien jurídico) se trata y su afectación efectiva es un criterio de referencia material para predicar un comportamiento como antijurídico $^{39}$, además de ser un límite al momento de la atribución de responsabilidad.

Y es ahí, justamente allí, anidando el concepto del principio de lesividad es donde cobra sentido interrogarnos si los fundamentos de algunas tipificaciones penales han quedado invalidadas por el desarrollo de las nuevas tecnologías, por el reconocimiento de nuevos derechos o porque le hemos dado otro contenido a los ya categorizados como derechos fundamentales.

Por ejemplo, basta con observar los efectos que se han suscitado con la preminencia que la Corte Constitucional de

39 BUSTOS RAMÍREZ, JUAN. Control Social y Sistema penal, Bogotá, Temis, 2012, p. 237. 4 
Colombia decidió darle a los derechos a la dignidad humana y el libre desarrollo de la personalidad en la sentencia C-221 de 1994, al declarar inexequible la norma ${ }^{40}$ que penalizaban las conductas -llevar consigo, conservar para su propio uso o consumir- dirigidas al consumo de "la definida legalmente» como "dosis personal»

Cada vez es más difícil (desde ese fallo hasta la fecha actual, me refiero) ofrecer una razón, un argumento que satisfaga la intervención estatal en la esfera privada del ciudadano, del destinatario último de la norma penal, pues la sola referencia a la peligrosidad abstracta de la conducta, sin poderse verificar en últimas la afectación que ella apareja para el bien jurídico, resulta insatisfactoria para cualquier conocedor de la lógica jurídica y el respetuoso de la dogmática penal.

Los esfuerzos por ocultar las sin razones nacionales, salvo la de proteger los intereses de la comunidad extranjera, la que se nos convirtió en un hábito, mejor aún, en un patrimonio cultural desde la época de la colonia, pueden evidenciarse en las sentencias de la Corte Constitucional: C-689 de 2002 ${ }^{41}$, C-574, C-882 de 2011 y C-491 de 2012; así como, en los siguientes fallos de la Corte Suprema de Justicia: SP-2940, 9 mar. 2016, rad. 41760; CSJ SP-4131, 6 abr. 2016, rad. 43512; y, CSJ SP-3605, 15 mar. 2017, rad. 43725.

Los malabarismos están a la orden del día. Algunas de las justificaciones plasmadas en las sentencias de casación del 11 de julio de 2017 y 11 de abril de 2018, SP9916-2017 y SP6062018, radicados 44997 y 47680, respectivamente, van desde el recurso pedagógico de señalarnos dónde se encuentra la norma

\footnotetext{
40 Ley 30 de 1986

${ }^{41}$ La Corte Constitucional declaró ajustado a la Carta Política el contenido del artículo 376 de la Ley 599 de 2000, en el entendido de la necesaria distinción entre el porte, conservación 0 consumo de sustancias estupefacientes en cantidad considerada como dosis destinada al uso personal y el narcotráfico como actividad ilícita alentada por el afán de lucro, resultando incuestionable la penalización de esta última como criterio político-criminal implícito en la tipificación de las conductas punibles que le son afines.
} 
que contiene la descripción del delito (tipo penal) ${ }^{42}$, pasando a invitarnos a "descubrir" el elemento subjetivo "implícito" en el tipo penal, hasta llegar a "enseñarnos" que por vía jurisprudencial es posible crear un nuevo verbo rector (porte con fines de venta). Eso de por sí ya nos da una vasta idea del irrespeto que le tenemos al principio de tipicidad.

En ese fallo se reconoce ese alto grado de dificultad al afirmar:

«Problemático ha resultado siempre en materia jurisprudencial la determinación del ámbito de lo prohibido en la regulación de la norma del artículo 376 del Código Penal, lo que ha girado alrededor del concepto de dosis permitida para el consumo personal y del principio de lesividad como factor de protección del bien jurídico de la salud pública tutelado por el legislador»

Y luego de evocar fallos de la Corte Constitucional y de auto-citarse concluye:

«resulta de la mayor importancia la consideración hecha por la Sala en el sentido que el tipo penal del artículo 376 del Código Penal, cuando la conducta se relaciona con el porte de estupefacientes, contiene un ingrediente subjetivo tácito, atinente al propósito del sujeto agente, por lo que la realización del tipo penal no depende en últimas de la cantidad de sustancia llevada consigo sino de la verdadera intención que se persigue a través de la acción descrita

(...)

\footnotetext{
42 La Corte Suprema de justicia, luego de hacer un rastreo jurisprudencial nos indica que en la sentencia C-491 de 2012 la Corte Constitucional de Colombia declaró ajustado al texto superior (constitución Política de Colombia) la norma actual del código penal (Ley 1453 de 2011 que modificó el artículo 376 de la Ley 599 de 2000) y que "razon[ó] de paso que la supresión de la expresión "salvo los dispuesto sobre dosis para uso personal" del tipo penal de "tráfico, fabricación o porte de estupefacientes", tal como fue descrito por el artículo 11 de la Ley 1453 de 2011, no puede interpretarse como una nueva penalización del porte y consumo de sustancias estupefacientes, sicotrópicas o drogas sintéticas, en cantidad considerada como "dosis personal" al tenor del artículo $2^{\circ}$ literal j) de la Ley 30 de 1986.
} 
Llegados a este punto, debe destacarse que la evolución del tema relacionado con el porte de estupefacientes -alusivo al verbo rector llevar consigo-, ha consolidado las siguientes tesis:

a) Tratándose de delitos de peligro abstracto -el previsto en el artículo 376 del Código Penal, lo es-, si bien en el momento de creación legislativa se deja implícita una presunción de peligro, esta es legal y no de derecho, por lo que el juez debe llevar a cabo un juicio de antijuridicidad a fin de determinar si se creó un riesgo efectivo, verificable empíricamente, para el bien jurídico protegido.

b) En todos los casos, el consumidor ocasional, recreativo o adicto, no puede ser considerado como sujeto pasible del derecho penal, cuando la conducta que realiza carece de cualquier connotación afín al tráfico o distribución de sustancias estupefacientes o psicotrópicas o drogas sintéticas, con independencia de la cantidad de sustancia prohibida que se lleve consigo, pues en tales eventos no se produce un efectivo menoscabo o peligro concreto para los bienes jurídicos que pueden ser objeto de tutela por el legislador.

c) Se reconoce la existencia de un elemento subjetivo implícito en el tipo penal, relacionado con la constatación de la intención del portador de la sustancia estupefaciente, debiéndose establecer si el propósito es el uso personal o si lo es la distribución o tráfico.

Si tan solo la jurisprudencia aceptara los rendimientos que ofrece aplicar el principio de lesividad a esta constelación de eventos, no tendríamos que forzar respuestas desde la parte subjetiva del tipo penal, en tanto éstas se podrían dar en sede de tipicidad objetiva, sin tener que exclamar con tristeza: ¡réquiem por la dogmática penal!

Corolario de lo anteriormente expuesto y a manera de conclusión parcial, el filtro que el funcionalismo nos ofreció con la teoría de la imputación objetiva, me refiero con ésta a todas los conceptos de acción jurídico penalmente desaprobada, riesgo 
no permitido, principio de confianza, posición de garante, etc., generó receptividad en la jurisprudencia de Colombia, en tanto se le observó como una herramienta lógica- argumentativa para construir respuestas satisfactorias a las problemáticas jurídicas que brotaban en nuestra caótica realidad.

Dicho de otro modo, el funcionalismo nos ha permitido ganarle la partida a la irracionalidad más que a la impunidad misma. Y por irracional me refiero a la respuesta emotiva dada sin fundamento alguno, a la solución visceral, a la intuitiva, a la que proviene del "palpito" o se le atribuye a la "visita" de cierta divinidad o ser celestial en la mente de los togados.

Empero, ni esa escuela del derecho penal, así como ninguna de las que le antecedieron, logran salvarnos de las sin- razones (emociones viscerales, criterios morales o subjetivos) por las que la jurisprudencia opta por aplicar indebidamente las categoría de la dogmática jurídico-penal.

\section{La dogmática penal de cara al sistema acusatorio}

En estrecha conexión con los lineamientos trazados en acápite anterior sobre la imputación objetiva, es del caso precisar que con la implementación del sistema acusatorio en Colombia se propugnó por activar mecanismos o herramientas procesales que permitieran descongestionar la administración de justicia, entre los cuales se cuenta: la orden de archivo por "atipicidad objetiva" ${ }^{43}$, la preclusión de la investigación por atipicidad (objetiva y subjetiva), los preacuerdos y el principio de oportunidad.

En el año 2002, esto es, tan sólo dos años después de haberse expedido un "Nuevo Código Procesal Penal: Ley 600

\footnotetext{
43 En los siguientes términos se desarrolló esa regla en la Ley 906 de 2004: ARTíCULO 79. ARCHIVO DE LAS DILIGENCIAS. Cuando la Fiscalía tenga conocimiento de un hecho respecto del cual constate que no existen motivos o circunstancias fácticas que permitan su caracterización como delito, o indiquen su posible existencia como tal, dispondrá el archivo de la actuación./Sin embargo, si surgieren nuevos elementos probatorios la indagación se reanudará mientras no se haya extinguido la acción penal.
} 
de 2000", el legislador colombiano empezó a gestar la forma, literalmente, para lograr remediar la crisis que afrontaba la administración de justicia por sus altos niveles de congestión o represamiento de proceso penales sin resolución judicial.

Mediante Acto Legislativo 03 de 2002 y la Ley 906 de 2004 en el ordenamiento jurídico colombiano ingresó el esquema procesal con tendencia acusatoria.

El principal motivo para cambiar el modelo procesal en el 2002 radicó en la crisis de la administración judicial por el represamiento de causas penales que prescribían. Entonces, se pensó en un modelo que incentivara las alternativas al conflicto, de tal manera que por esas vías se procesaran la mayoría de casos penales y se le pusiera coto a los efectos del expansionismo del derecho penal (en contraposición al derecho penal minimo, a la última ratio), otro mal que nos aqueja por el manejo inadecuado de los principios de la dogmática jurídico penal con el interés más ruin que es la de abarcar una constelación de casos que son propios del derecho administrativo o, en su defecto, del policivo, pues sus protagonistas son congresistas, gobernadores, alcaldes, en últimas políticos a quienes sus opositores desean truncarles sus postulaciones a cargos de elección popular.

Empero, no nos llamemos a engaños, la aplicación exitosa de cada una de las nuevas figuras procesales prenombradas depende del buen intérprete de quien haga uso adecuado de los principios de la dogmática jurídico penal y, porqué no reconocerlo, fueron dispuestas para acoplarse y complementarse con los réditos que ofrece la teoría de la imputación objetiva, en tanto ésta actúa como un filtro para desestimar ejercer la acción penal ${ }^{44}$ respecto a centenares de hechos denunciados

\footnotetext{
44 La acción penal solo se activará en aquellos eventos en que se constate o verifique que los hechos denunciados revisten las características de un delito 0, mejor aún, cuando la conducta denunciada se adecua a alguno de los comportamientos descritos en la legislación penal sustantiva y, por tanto, es típica objetivamente, ver al respecto: CSJ, AP 336 -2017, radicado 48759 .
} 
que no revisten las características de un delito (art. 250 de la Constitución Política de Colombia de 1991) ${ }^{45}$.

Por tanto, con la nueva o la vieja legislación procesal penal se habría podido obtener la finalidad tan deseada de descongestionar la administración de justicia, pues basta con que las partes procesales (Fiscalía y defensa), los intervinientes (Víctima y Ministerio Público) y el juez respetara la dogmática jurídico penal, en cualesquiera de las distintas escuelas del derecho penal con la que se sienta complacido de exponer su teoría del caso o la hipótesis de los hechos objeto de investigación que de conformidad a las evidencias o a las pruebas practicadas en el juicio oral se logró reconstruir, respectivamente.

Con la implementación del nuevo esquema procesal con tendencia acusatoria mutó el concepto de "acción penal ${ }^{46}$ que se tenía en el sistema de corte inquisitivo anterior; variación que, a su vez, exigía una mayor formación académica del personal que integra a la Fiscalía General de la Nación, en tanto éstos funcionarios públicos serían los primeros receptores $\mathrm{y}$ analíticos de los hechos objeto de denuncia.

45 En cuanto a la orden de archivo por atipicidad podemos señalar que el artículo 250 de la Constitución Nacional prevé: "La Fiscalía General de la Nación está obligada a adelantar el ejercicio de la acción penal y realizar la investigación de los hechos que revistan las características de un delito que lleguen a su conocimiento por medio de denuncia, petición especial, querella o de oficio, siempre y cuando medien suficientes motivos y circunstancias fácticas que indiquen la posible existencia del mismo".

46 «El fundamento de... dos posiciones antagónicas... reside en la consideración de si sólo hay acción penal cuando se está frente a la posibilidad de un hecho delictivo pero no cuando la investigación demuestra que ha existido conducta punible bien sea porque no se ha ejecutado ningún comportamiento o porque el investigado no pueda subsumirse en una norma penal. 0 bien la acción penal es independiente de esa situación y persiste aun en el caso de que se demuestre el extremo planteado en último término. La cuestión solo puede resolverse al establecer la naturaleza de la acción penal. Sobre este particular se han enunciado dos tesis principales: una que la considera manifestación de la pretensión punitiva del Estado, es decir, como un derecho de éste a sancionar los delitos y que se vincula necesariamente a la existencia de un ilícito penal.

Y otra, que la estima independiente de la pretensión punitiva y encaminada sólo a poner en movimiento la función jurisdicción del Estado con miras a obtener de las autoridades correspondientes un pronunciamiento en cualquier sentido." (Subrayas fuera del texto principal). CSJ, AP 17 mayo 2007, radicado 24374, reiterada en AP336-2017, radicado 48759. 
Para la muestra un botón! Tuve la fortuna de cursar en el año 2009 la especialización de procesal penal en la Universidad Externado de Colombia con un grupo de agentes de la Policía Nacional y de la Fiscalía General de la Nación, precisamente, porque el interés para aquel entonces, era adoctrinarnos en las herramientas que nos permitieran poner en funcionamiento todas aquellas válvulas de escape, si se me permite la metáfora, que nos condujeran a descongestionar los despachos judiciales de conductas que no eran jurídico- penalmente relevantes, siendo una de las materias obligadas a cursar la que se denominaba: Teoría de la imputación objetiva. Aplicando, por ejemplo, "El concepto jurídico penal de acción", de JAKOBS ${ }^{47}$, a partir del cual sólo sería objeto de persecución penal quien haya creado un riesgo jurídico desaprobado.

Respecto ese tópico resulta ilustrativo el análisis de los siguientes elementos fácticos:

Un día sábado a las 14 horas y 30 minutos, aproximadamente, Arturito $^{48}$, un Fiscal Especializado de la unidad de Justicia y Paz, se transportaba en un vehículo de su propiedad, en compañía de su novia, ocupante del puesto delantero derecho, de su mamá y sus hermanos, quienes se encontraban en el asiento trasero. Mientras esperaban el cambio de luz del semáforo de una calle de la ciudad de Medellín (Antioquía), fueron interceptados por dos personas que se movilizaban en motocicleta: MOSCÚ ${ }^{49}$, quien se ubicó al costado derecho del vehículo y alias "muelas", por el izquierdo. MOSCÚ de manera intempestiva, desde su rodante de placas LCX 440B, desenfundó un arma tipo revolver, color plateado, y desde la ventana entreabierta del "copiloto" apuntó a los ocupantes de la camioneta. Frente a este escenario, el Fiscal Especializado

\footnotetext{
47 JAKOBS G, El concepto jurídico penal de acción, Editorial UNIVERSIDAD EXTERNADO DE COLOMBIA, 1996. ISBN 958-616-232, página 26.

48 Se modifica el nombre del indiciado para garantizar sus derechos, entre ellos, el derecho a la autodeterminación informativa, en su versión del derecho al olvido.

49 Ejusdem.
} 
reaccionó inmediatamente y disparó contra el referido agresor, quien recibió el impacto de bala en el cuello que derivó en la pérdida de la sensibilidad y movilidad en sus extremidades; mientras que alias "muelas" abandonó el lugar al ver la acción defensiva del investigado.

Los reseñados hechos fueron objeto de análisis por la Sala Penal de la Corte Suprema de Justicia de Colombia en auto del 7 de marzo de 2018 (AP979-2018), radicado 50095, accediéndose a la preclusión de la investigación adelantada a Arturito, reconociéndosele haber actuado en legítima defensa, expresando las siguientes razones:

«La situación fáctica en este proceso no ofrece dificultad, toda vez que el video allegado por el ente acusador, así como las declaraciones de las personas mencionadas en esta decisión, revelan que una camioneta se moviliza a baja velocidad, por vía pública, momentos antes de detenerse al tiempo con todos los automotores que transitaban en la misma calle./ Detenido el tráfico, dos motociclistas, de forma coordinada, desde atrás se acercan por cada lado, y cuando el reloj de la cámara registra las 14:22:49, el motorizado ubicado por el lado derecho introduce un arma por la ventana del pasajero de adelante y transcurrido un segundo (14:22:50) de manera abrupta, el agresor cae sobre el costado del vehículo del agredido, con ocasión de un disparo que hizo éste. /Los hechos así expuestos y que no han sido cuestionados por nadie, sin duda ponen de presente que quien reaccionó lo hizo dentro del marco de la causal excluyente de responsabilidad postulada por el Fiscal. La persona que resultó lesionada, en la entrevista allegada por la Fiscalía admite que su compañero de delito "muelas" eligió al hombre que manejaba la referida camioneta para quitarle la cadena de oro y la "joyería" que llevaba; así mismo, describió que su función en el plan criminal era apuntarle al conductor con el arma de fogueo; en términos precisos narró: "yo le llegué al carro como habiamos quedado, yo le pelé el mentiroso, no digo nada y fue cuando sentí el disparo". También aceptó que la persona a atacar era al 
conductor, pues se desconocía si había acompañantes dentro del carro, ya que el vehículo tenía en sus ventanas "un nivel polarizado 2 o sea muy oscuro".

La circunstancia de esgrimir un arma para intimidar a una persona y sobre esa base buscar doblegarla para hacerla víctima de una conducta punible, actualiza el ataque a que se refiere la eximente, además que ubica al sujeto que ejecuta ese comportamiento en situación de injusticia, y no permite considerar algo diferente al afectado de hallarse frente a un acto violento, con la inminencia de materializarse desde el punto de vista físico, ante lo cual le es lícito reaccionar, que fue justamente lo que hizo el indiciado, de modo que se satisfacen los requisitos de injusticia y actualidad.

Que después se haya determinado que el instrumento utilizado por el agresor no correspondía a un arma de fuego, sino a una imitación, tal circunstancia no desnaturaliza la legítima defensa, como quiera que no es dable exigir a quien reacciona que establezca primero la condición del arma con la cual se busca intimidarlo y dentro de ese contexto decida si ejecuta un acto de repulsa o no, toda vez que es claro que las circunstancias apremiantes del momento no son las apropiadas para llevar a cabo procesos de reflexión de esa índole.

(...)

Entonces, sopesados los argumentos expuestos por los intervinientes y confrontados con los acontecimientos reflejados en el video, así como las entrevistas rendidas por los testigos; para la Sala no hay duda que el procesado actuó bajo la figura jurídica de la legítima defensa objetiva, no como lo sostuvo el apoderado de la víctima que aquí se configuraría una defensa subjetiva, que es un típico caso de error, pues del contexto de los hechos se aprecia cabalmente que el mencionado no se imaginó o supuso que era objeto de una agresión, sino que esta existió."»

Evidente es que la Corte aceptó que la acción del indiciado, esto es, el actuar del Fiscal Especializado se encontraba 
"justificada" por tratarse de una legítima defensa, haciendo uso en algunos momentos de los postulados de la teoría de la imputación objetiva para desestimar la respuesta que los impugnantes (Ministerio Público y víctima) solicitaba se les diera desde el finalismo, referida ésta a reconocer un error de tipo permisivo (error de prohibición indirecto), esto es, que aquel había incurrido en un error sobre los presupuestos fácticos de la causal justificante de la legítima defensa, al desconocer que se le había intimidado con un arma de fogueo.

Evidente es que desde los postulados de la imputación objetiva la respuesta a esa problemática hubiese sido disímil, bajo el entendido que el comportamiento del indiciado (Fiscal Especializado) se trataba de una acción jurídicamente aprobada por el derecho penal. La imputación del resultado lesivo causado a quien resolvió desenfundar un arma de fogueo, si acaso, era positiva. Por tanto, estaríamos hablando no de un comportamiento justificado, de un caso a resolverse en sede de antijuridicidad, sino de una acción o atipicidad objetiva. Huelga recordar aquí lo manifestado por JAKOBS:

«la imputación objetiva elimina a modo de filtro todos aquellos comportamientos que no perturban socialmente, también aquello que pueda imputarse positivamente: no es esta la imputación de la que aqui se trata. Lo que queda es lo que crea riesgos no permitidos, esto es, lo que causa una lesión de la vigencia de la norma en caso de concurrir evitabilidad y culpabilidad... A diferencia de lo que ocurría con el concepto de acción de Welzel, que por ser ajeno a la sociedad (aunque no fuese voluntario ese desligamiento) también abarcaba cualesquiera actos finales, en el marco del concepto de acción que aquí se defiende, únicamente son relevantes actos que responden a unas determinadas características. Desde el punto de vista del Derecho Penal, la acción siempre y en todo caso sólo es algo socialmente inadecuado ${ }^{50}$

50 JAKOBS G, El concepto jurídico penal de acción, Editorial UNIVERSIDAD EXTERNADO DE COLOMBIA, 1996. ISBN 958-616-232, página 50. 
Causa desazón que la jurisprudencia soslaye adelantar el análisis de los postulados de la teoría del derecho penal en que funda su respuesta, esto es, la del funcionalismo, descendiendo al peldaño de la antijuridicidad para reconocer la causal justificante de la legítima de defensa, desestimando la configuración de la defensa putativa alegada por los apelantes, cuando debió concluir que era atípica la conducta del indiciado al aplicar el concepto de "acción socialmente adecuada" o de "riesgo jurídicamente aprobado".

La Corte no dio respuesta satisfactoria a las apelaciones de los intervinientes en esa indagación penal, pues, reitero, no se les señaló porqué se desestimaban los fundamentos que éstos invocaban, referidos a reconocer un error de tipo permisivo. Y, quizás, por no decir como un hecho cierto, que si le pudiera interrogar a la Corte las razones por las que guardó silencio al respecto, probablemente la respuesta sería que no requería dar tales explicaciones porque al fin y al cabo la respuesta por la vía del finalismo o del funcionalismo conducían a tener: el comportamiento como justificado.

Empero, lo cierto es que esa clase de decisiones terminan convidándonos a deslizarnos en terrenos pantanosos de una aguda ceguera jurídica que en manera alguna contribuye a mejor la imagen de una administración de justicia imparcial y transparente, pero sobre todo garantista de podernos ofrecer seguridad jurídica.

También se han venido dando palos de ciego en el tema de los allanamientos a cargos y los preacuerdos. Así, incluso, en sentencia del 27 de septiembre de 2017, la Sala de Casación Penal de la Corte Suprema de Colombia lo aceptó.

La necesidad de que la jurisprudencia aborde el análisis de los problemas jurídicos que se le plantean basándose en unos principios de la dogmática jurídico penal en concreto evita la arbitrariedad, el capricho y, al mismo tiempo, ratifica lo que bien nos señala VERGARA, al decir: 
"La dogmática no es un simple y singular ejercicio de gimnasia intelectual; sino un sistema ordenado de pasos para solucionar casos de la forma más racional y coherente posible, alejando las decisiones judiciales en esta área, del arbitrio del operador judicial. Desde Feuerbach $y$ Von Liszt, este ha sido el anbelo de la ciencia del derecho penal, ${ }^{51}$.

\section{La dogmática penal de cara a la justicia transicional}

- En el 2003, el gobierno de turno (Álvaro Uribe Vélez) y los principales dirigentes de las Autodefensas Unidas de Colombia (AUC) suscriben un acuerdo, en el cual 30 mil miembros de esa organización armada y sus comandantes se comprometieron a cesar sus "operaciones bélicas" a cambio de que se les sometiese a un procedimiento de "alternatividad penal", en el que, a la postre, se les impondría una pena simbólica (ocho años de privación de la libertad intra-mural) hasta lograr su resocialización.

- Para el año 2005, el congreso de la República y el gobierno promulgan y sancionan, respectivamente, la Ley 975, dispositivo normativo al que se le denominó "Ley de justicia y paz", al promover un proceso de desmovilización masiva de grupos ilegales alzados en armas, principalmente de las AUC.

- 13 de mayo de 2008. Algunos comandantes de las AUC desmovilizados fueron extraditados a U.S.A. La decisión del gobierno de permitir su extradición se basaba en el argumento de que estos seguían delinquiendo desde las cárceles.

- En el 2009, el número de desmovilizados llegó ascender a 50.000, unos 32.500 de las autodefensas, 15.000 de las FARC y 2.500 del ELN.

- El 24 de agosto de 2016 los representantes del Estado de Colombia y las Fuerzas Armadas Revolucionarias de Colombia -FARC- suscribieron un documento intitulado: "El acuerdo final

51 VERGARA SALGADO, GUSTAVO. “El tratamiento del error de tipo permisivo en la legislación penal colombiana", tesis de maestría. Universidad Externado de Colombia. 2017, pág. 10. 
para la terminación del conflicto y la construcción de una paz estable y duradera".

La sentencia del 23 de febrero de $2010^{52}$, proferida por la Sala Penal de la Corte Suprema de justicia de Colombia, con la cual se puso fin al proceso penal que se le adelantó al congresista ÁLVARO ALFONSO GARCÍA ROMERO es quizás la que mejor ilustra la aplicación de los postulados de la imputación objetiva a esta clase de hechos ocurridos en el entramado que previamente reseñé, al aludir al concepto de autoría mediata a través de aparatos organizados de poder, toda vez que se trataba nada más que del co-fundador del grupo de las Autodefensas Unidas de Colombia "Frente Héroes de los Montes de María", el cual operaba en el departamento de Sucre con una estructura de jerarquía en la que los altos mandos diseñaban las conductas delictivas a realizar y sus subordinados las ejecutaban.

Entre el 9 y 16 de octubre de 2000 esa agrupación paramilitar perpetró múltiples homicidios y desplazamiento forzado en el municipio de Carmen de Bolívar, específicamente, contra los pobladores de Macayepo.

Empecemos por señalar que hasta antes de esa decisión, la jurisprudencia había mantenido una tesis en la que, pacíficamente, se distinguía entre el sujeto agente que intervenía como determinador y el que actuaba como autor mediato, básicamente, porque éste último actuaba a través de ejecutores materiales que no estaban en posición de decidir si realizaban la conducta típica porque sus "roles como ejecutores materiales habian sido impuestos por el autor mediato" y "no eran conscientes de la real dimensión de sus roles"

\footnotetext{
52 Huelga aclarar que la referida sentencia condenatoria proferida contra GARCÍA ROMERO se ha anunciado va ser objeto de revisión por la Justicia Especial para la Paz, pues así lo peticionó el sentenciado, razón por la cual la ubiqué en este ítem, aguardando el pronunciamiento oficial de dicho cuerpo colegiado.

53 MUÑOZ CONDE, F. La aplicación del concepto de autoría mediata a través de aparatos organizados de poder en América Latina y España, Doctrina. Revista Penal México, núm 1. Enero-junio de 2011.
} 
Como bien atina a señalarlo MUÑOZ CONDE "esa renuncia de la Corte Suprema de Colombia en aplicar el concepto de autoría mediata a través de aparatos organizados de poder" fue superada, al menos parcialmente, en esa decisión, al tenerse en cuenta los siguientes dos factores:

"Las instrucciones impartidas por los comandantes de más alto rango del grupo resultaban bastante detalladas, y la discrecionalidad para ponerlas en marcha por los comandantes desplegados en el terreno y los miembros del grupo de bajo rango, fue muy limitada.

Las numerosas reuniones y las continuas comunicaciones vía radial y telefónica entabladas entre los comandantes de más alto rango del grupo y sus comandantes desplegados en el terreno permitió a los primeros mantener un estricto dominio y control sobre el desarrollo de las operaciones del grupo".

Y se dice "parcialmente" porque en esa misma sentencia la Corte declaró penalmente responsable al procesado GARCÍA ROMERO por el homicidio de GEORGINA NARVAEZ, pero en calidad de determinador, aun contándose con los mismos factores probatorios anteriormente reseñados.

Resulta oportuno replicar la misma crítica que hice en el ítem anterior, en cuanto a que la jurisprudencia no tuvo reparo alguno en aplicar la figura de determinación y de autor mediato, sin un argumento sólido o coherente, más allá de que la respuesta punitiva consagrada en la legislación penal era la misma, toda vez que en los artículos 29 y 30 se le asigna a aquel y a éste la misma pena.

Ley 599 de 2000:

ARTICULO 29. AUTORES. Es autor quien realice la conducta punible por sí mismo o utilizando a otro como instrumento.

Son coautores los que, mediando un acuerdo común, actúan con división del trabajo criminal atendiendo la importancia del aporte. 
También es autor quien actúa como miembro u órgano de representación autorizado o de hecho de una persona jurídica, de un ente colectivo sin tal atributo, o de una persona natural cuya representación voluntaria se detente, y realiza la conducta punible, aunque los elementos especiales que fundamentan la penalidad de la figura punible respectiva no concurran en él, pero sí en la persona o ente colectivo representado.

El autor en sus diversas modalidades incurrirá en la pena prevista para la conducta punible.

ARTICULO 30. PARTICIPES. Son partícipes el determinador y el cómplice.

Quien determine a otro a realizar la conducta antijurídica incurrirá en la pena prevista para la infracción.

Quien contribuya a la realización de la conducta antijurídica o preste una ayuda posterior, por concierto previo o concomitante a la misma, incurrirá en la pena prevista para la correspondiente infracción disminuida de una sexta parte a la mitad.

$\mathrm{Al}$ interviniente que no teniendo las calidades especiales exigidas en el tipo penal concurra en su realización, se le rebajará la pena en una cuarta parte.

Una vez más se sacrificó los principios de la dogmática jurídico- penal para hacer prevalecer los criterios morales de los togados, pretextándose que no habría diferencia alguna en una y otra teoría, en cuanto a que el monto punitivo a imputarle sería el mismo, lo cual resulta una justificación más endeble o frágil aún para aducirse ante la justicia transicional, por no decir negativamente ejemplificadora para los servidores públicos que han de proferir las decisiones en estos tribunales especiales, pues tanto a los paramilitares como los miembros de la FARC que se acogieron a los procesos de paz el Presidente de turno les garantizó la aplicación de un pena simbólica, la cual asciende tan solo a 8 y 5 años de prisión, respectivamente.

Entonces ¿Debe entenderse que en estos casos no deben desgastarse el intérprete y el operador jurídico (los magistrados) 
en verificar cuál fue el grado de participación del exparamilitar o del exguerrillero en las masacres, tortura, desplazamiento forzado y otras conductas delictivas, porque resulta inane hacer la diferenciación y distinción porque, al fin y al cabo, la pena será la misma? Por supuesto que la respuesta a ese interrogante debe de ser negativa, pues en manera alguna podemos olvidar el mensaje simbólico que deseaba enviar ROXIN, el creador, justamente, de la teoría de los aparatos organizados de poder, la cual fue parcialmente aplicada por la jurisprudencia, quizás, porque no fue comprendida en su plenitud. Una vez más solo podría exclamarse: "Réquiem por la dogmática penal".

\section{Conclusiones}

1. La jurisprudencia de Colombia fue receptiva a los postulados de la teoría de la imputación objetiva, toda vez que actuaron como verdaderos filtros, contribuyendo a descongestionar la administración de justicia, toda vez que a partir de esa teoría se nos cita a auscultar si se trata de un comportamiento jurídico-penalmente desaprobado aquel hecho denunciado que, aparentemente, reviste las características de un delito de cara a la descripción típica prevista en la legislación penal.

2. La coherencia que el discurso del funcionalismo nos ofrece es, quizás, otra de las razones por la que la jurisprudencia colombiana se ha mostrado receptiva a la teoría de la imputación objetiva, en tanto que los conceptos que ésta postula se articulan como verdaderas herramientas lógicas- argumentativas, lo cual permite construir respuestas satisfactorias a las problemáticas jurídicas que brotaban en nuestra caótica realidad.

3. El funcionalismo nos ha permitido ganarle la partida a la irracionalidad más que a la impunidad misma. Y por irracional me refiero a la respuesta emotiva dada sin fundamento alguno, a la solución visceral, a la intuitiva, a la que proviene del "palpito" o se le atribuye a la "visita" de cierta divinidad o ser celestial en la mente de los togados. 
4. No es cierto que el sistema penal acusatorio o la justicia transicional per se logren poner en jaque a la dogmática jurídicopenal sino que, por el contrario, incentivan al uso adecuado de cada uno de sus postulados o de los principios de cada doctrina o escuela del derecho penal. La ignorancia, la tozudez, la ceguera jurídica del intérprete de la ley sí han de aducirse o considerarse como verdaderas causas de que exclamemos con frecuencia: réquiem por la dogmática penal.

Debo señalar, como advertí en un principio, que en el presente trabajo me he limitado a reseñar unas cuantas heridas, pues el problema enunciado exige un estudio más detallado y profundo, toda vez que la muerte de la dogmática jurídicopenal que motiva este réquiem ha sido producto de un crimen pasional cometido con sevicia durante más de 100 años.

\section{Bibliografía, fuentes WEB, y tabla de la jurisprudencia analizada}

- $\quad$ RAFECAS, D. "El crimen de tortura. En el Estado autoritario y en el Estado de Derecho.” Editorial Didot, páginas 408 y 409.

- http://babel.banrepcultural.org/cdm/singleitem/collection/ p17054coll10/id/643

- http://www.elcolombiano.com/colombia/la-toma-del-palaciode-justicia-una-herida-sin-cerrar-AI3028417

- NARANJO GIRALDO, GLORIA. http://www.ub.edu/geocrit/ sn-94-37.htm

- http://www.eltiempo.com/archivo/documento/MAM-684002

- "Los ríos que las FARC pintaron de Negro", publicado por Resistencia democrática, ver en: www.resistenciacivildemocratica.org/terrorismo/terror15jun.php

- https://www.youtube.com/watch?v=EN1iqWOFIU

- CORCOY BIDASOLO, MIRENTXU. "Imputación objetiva y principio de lesividad", Revista Argentina de Derecho Penal y Procesal Penal Número 1. Noviembre de 2011. Fuente de consulta: http://www.ijeditores.com.ar/articulos.php?idarticulo $=47797 \&$ print $=2$ 
- $\quad$ ROXIN C, Derecho Penal, parte general, tomo I. Fundamentos. La estructura de la Teoría del delito. Editorial Civitas S.A. 1997, página 207.

- JAKOBS G, El concepto jurídico penal de acción, Editorial UNIVERSIDAD EXTERNADO DE COLOMBIA, 1996. ISBN 958616-232, página 26.

- LOPEZ DIAZ, CLAUDIA. "Introducción a la imputación objetiva”. Colección de estudios No. 5. Universidad Externado de Colombia. Centro de Investigaciones de Derecho Penal y Filosofía del Derecho

- SCHÜNEMANN, Bernd, Temas actuales y permanentes del derecho penal después del milenio, Tecnos, Madrid, 2002, p. 73

- WELZEL, Hans, Derecho penal alemán, Editorial Jurídica de Chile, Santiago, 1970, p. 97).

- SISCO, Luis P. La Defensa Justa. Librería "El Ateneo" Editorial. Buenos Aires, 1949.

- MUÑOZ CONDE, F. La aplicación del concepto de autoría mediata a través de aparatos organizados de poder en América Latina y España, Doctrina. Revista Penal México, núm 1. Enero-junio de 2011

- http://www.elpais.com.co/proceso-de-paz/las-polemicas-revelaciones-de-promotor-del-no-sobre-estrategia-en-el-plebiscito. html, https://www.elespectador.com/noticias/politica/cuestionable-estrategia-de-campana-del-no-articulo-658862

- http://www.medicinalegal.gov.co/web/guest/noticias?p_p_ id=com_liferay_asset_publisher_web_portlet_AssetPublisherPortlet_INSTANCE_vLcVEedo8qgD\&p_p_lifecycle $=0 \& p \_p \_$ state $=$ normal\&p_p_mode $=v i e w \&$ \&com_liferay_asset_publisher_web_portlet_AssetPublisherPortlet_INSTANCE_vLcVEedo8qgD_delta=7\&p_r_p_resetCur=false\&_com_liferay_asset_ publisher_web_portlet_AssetPublisherPortlet_INSTANCE_ vLcVEedo8qgD_cur=39

- http://www.elcolombiano.com/colombia/muertes-por-el-conflicto-en-colombia-se-redujeron-medicina-legal-AB6892376 


\begin{tabular}{|c|c|c|}
\hline $\begin{array}{l}\text { SENTENCIA, } \\
\text { radicado: }\end{array}$ & FECHA & Principal tema tratado \\
\hline Sentencia & 11 de noviembre de 1986 & Causalismo Vs. Finalismo \\
\hline 9651 & 24 de octubre de 1995 & $\begin{array}{l}\text { Riesgo jurídicamente } \\
\text { desaprobado. Lex artis. }\end{array}$ \\
\hline 9781 & 10 de julio de 1997 & Con- causalidad \\
\hline 10776 & 12 de noviembre de 1999 & $\begin{array}{l}\text { Teoría de la equivalencia de } \\
\text { las condiciones }\end{array}$ \\
\hline 33116 & 28 de julio de 2010 & $\begin{array}{l}\text { Teoría de la equivalencia de } \\
\text { las condiciones }\end{array}$ \\
\hline 12655 & 16 de septiembre de 1997 & Principio de confianza \\
\hline 32582 & 28 de octubre de 2009 & Principio de confianza \\
\hline 38904 & 26 de julio de 2013 & Principio de confianza \\
\hline 21770 & 30 de junio de 2004 & $\begin{array}{l}\text { Principio de confianza en } \\
\text { Peculado culposo }\end{array}$ \\
\hline 24031 & 28 de septiembre de 2006 & $\begin{array}{l}\text { Principio de confianza en } \\
\text { Peculado culposo }\end{array}$ \\
\hline 19988 & 27 de mayo de 2003 & $\begin{array}{l}\text { Delito contra la } \\
\text { administración pública y } \\
\text { Principio de confianza }\end{array}$ \\
\hline 47100 & 18 de enero de 2015 & $\begin{array}{l}\text { Delito contra la } \\
\text { administración pública y } \\
\text { Principio de confianza }\end{array}$ \\
\hline 12742 & 4 de abril de 2003 & Principio de confianza \\
\hline 35899 & 5 de diciembre de 2011 & Principio de confianza \\
\hline 16636 & 20 de mayo de 2003 & Principio de confianza \\
\hline 32964 & 25 de agosto de 2010 & $\begin{array}{l}\text { Dolo eventual y culpa con } \\
\text { representación. Posición de } \\
\text { garante. }\end{array}$ \\
\hline 45008 & 15 de diciembre de 2015 & $\begin{array}{l}\text { Dolo eventual/ culpa con } \\
\text { representación }\end{array}$ \\
\hline 45321 & 25 de mayo de 2015 & $\begin{array}{l}\text { Dolo eventual/ Culpa con } \\
\text { representación }\end{array}$ \\
\hline 50095 & 7 de marzo de 2018 & $\begin{array}{l}\text { Legítima defensa/ defensa } \\
\text { putativa }\end{array}$ \\
\hline 39831 & 27 de septiembre de 2017 & $\begin{array}{l}\text { Tipicidad en allanamiento a } \\
\text { cargos y preacuerdos. }\end{array}$ \\
\hline $\begin{array}{l}\text { AP336-2017, } \\
\text { rad.48759 }\end{array}$ & 25 de enero de 2017 & $\begin{array}{l}\text { Acción penal en el sistema } \\
\text { acusatorio }\end{array}$ \\
\hline
\end{tabular}

